ORNL/TM-2014/335

\title{
National Weatherization Assistance Program Impact Evaluation - Client Satisfaction Survey: WAP Service Delivery from the Client's Perspective
}

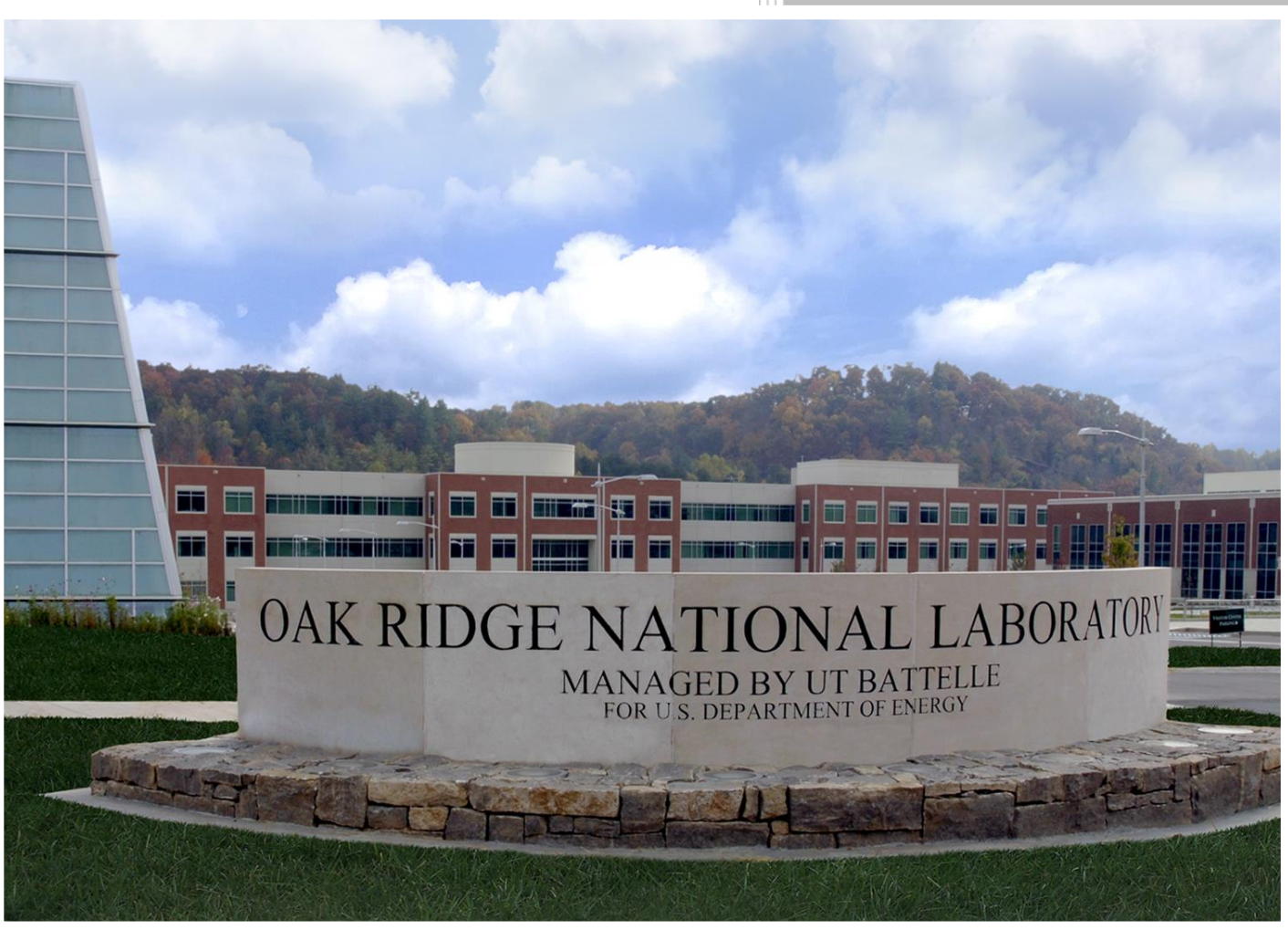

David Carroll Jacqueline Berger Carolyn Miller Colleen Driscoll

September 2014 


\title{
DOCUMENT AVAILABILITY
}

Reports produced after January 1, 1996, are generally available free via US Department of Energy (DOE) SciTech Connect.

Website http://www.osti.gov/scitech/

Reports produced before January 1, 1996, may be purchased by members of the public from the following source:

\author{
National Technical Information Service \\ 5285 Port Royal Road \\ Springfield, VA 22161 \\ Telephone 703-605-6000 (1-800-553-6847) \\ TDD 703-487-4639 \\ Fax 703-605-6900 \\ E-mail info@ntis.gov \\ Website http://www.ntis.gov/help/ordermethods.aspx
}

Reports are available to DOE employees, DOE contractors, Energy Technology Data Exchange representatives, and International Nuclear Information System representatives from the following source:

Office of Scientific and Technical Information

PO Box 62

Oak Ridge, TN 37831

Telephone 865-576-8401

Fax 865-576-5728

E-mail reports@osti.gov

Website http://www.osti.gov/contact.html

This report was prepared as an account of work sponsored by an agency of the United States Government. Neither the United States Government nor any agency thereof, nor any of their employees, makes any warranty, express or implied, or assumes any legal liability or responsibility for the accuracy, completeness, or usefulness of any information, apparatus, product, or process disclosed, or represents that its use would not infringe privately owned rights. Reference herein to any specific commercial product, process, or service by trade name, trademark, manufacturer, or otherwise, does not necessarily constitute or imply its endorsement, recommendation, or favoring by the United States Government or any agency thereof. The views and opinions of authors expressed herein do not necessarily state or reflect those of the United States Government or any agency thereof.

\section{ORNL Principal Investigator}

Dr. Bruce Tonn

\section{Evaluation Team Task Manager Jacqueline Berger, Ph.D.}


Environmental Sciences Division

\title{
NATIONAL WEATHERIZATION ASSISTANCE PROGRAM IMPACT EVALUATION - CLIENT SATISFACTION SURVEY: WAP SERVICE DELIVERY FROM THE CLIENT'S PERSPECTIVE
}

\author{
David Carroll, APPRISE \\ Jacqueline Berger, Ph.D., APPRISE \\ Carolyn Miller, Carolyn Miller Consulting \\ Colleen Driscoll, APPRISE
}

Date Published: September 2014

\author{
Prepared by \\ OAK RIDGE NATIONAL LABORATORY \\ Oak Ridge, Tennessee 37831-6283 \\ managed by \\ UT-BATTELLE, LLC \\ for the \\ US DEPARTMENT OF ENERGY \\ under contract DE-AC05-00OR22725
}





\section{CONTENTS}

Page

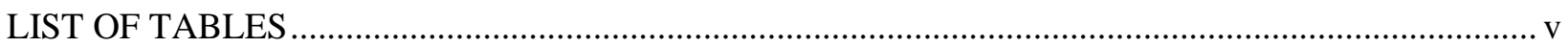

ACRONYMS AND ABBREVIATIONS ........................................................................... vii

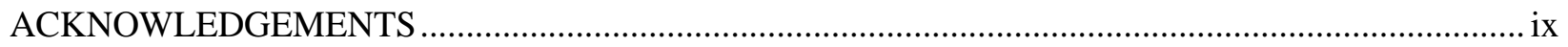

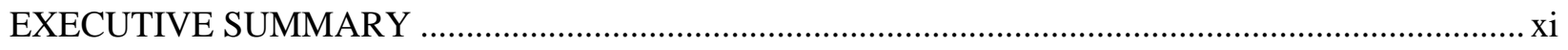

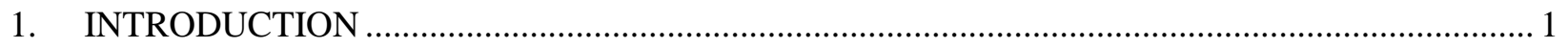

1.1 NATIONAL WEATHERIZATION ASSISTANCE PROGRAM EVALUATION

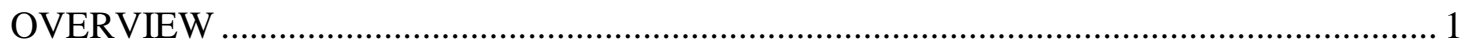

1.2 SATISFACTION SURVEY STUDY OVERVIEW ..................................................... 2

1.3 ORGANIZATION OF THE CLIENT SATISFACTION SURVEY REPORT ....................... 2

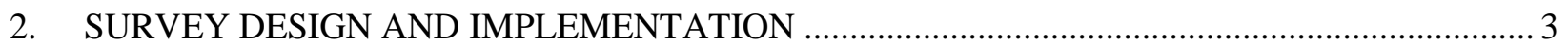

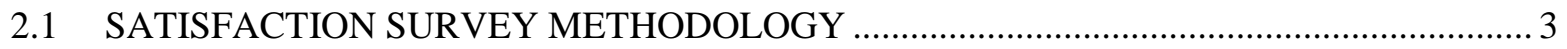

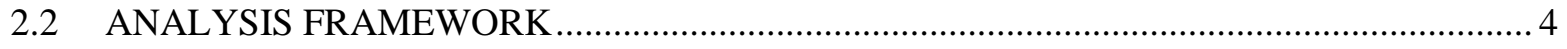

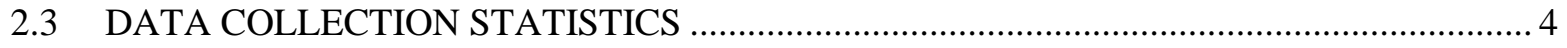

3. SATISFACTION WITH THE WEATHERIZATION PROCESS ……......................................... 7

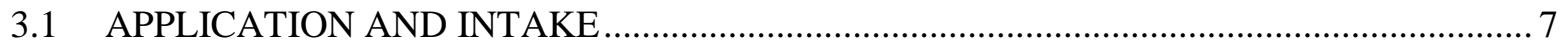

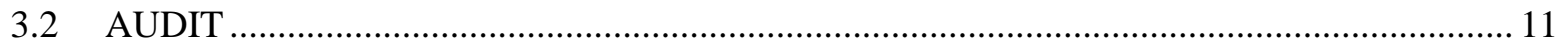

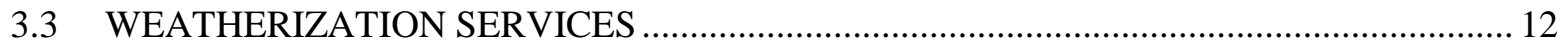

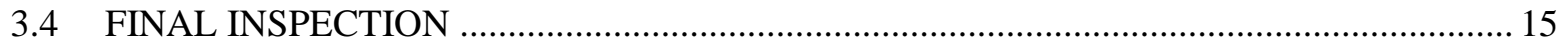

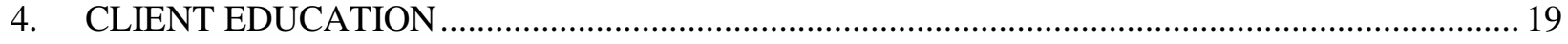

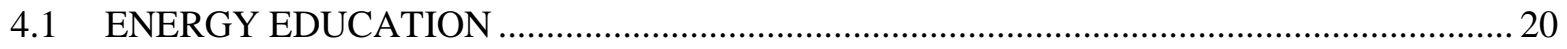

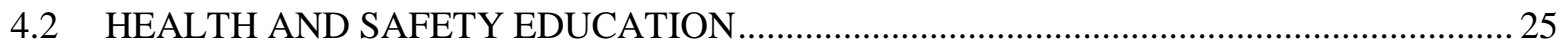

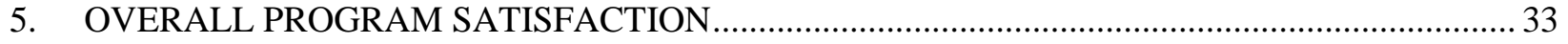

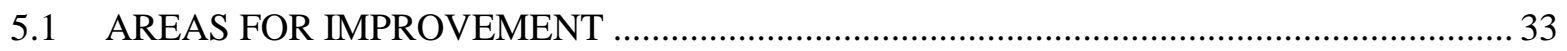

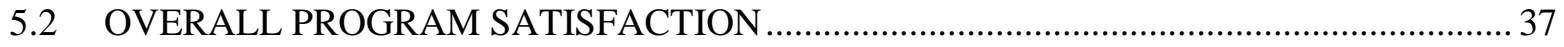

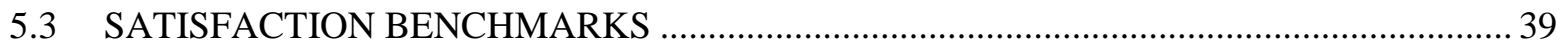

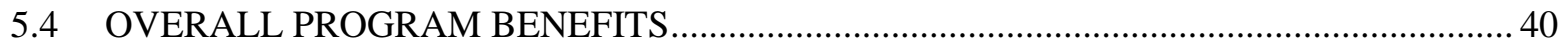





\section{LIST OF TABLES}

Table

Page

Table 1 Overall Satisfaction with Key Components of the Program ........................................................

Table 2 Ease of Dealing with Different Aspects of the Program .................................................................

Table 3 Timeliness of Various Components of the Program .................................................................. xvi

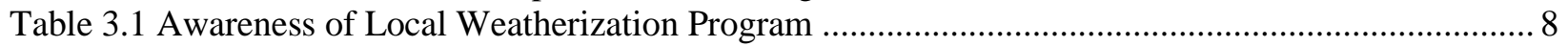

Table 3.2 How Learned about Local Weatherization Program........................................................... 8

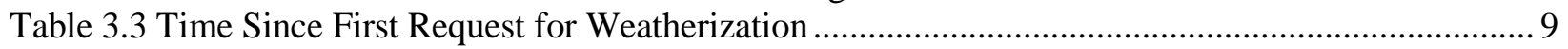

Table 3.4 Satisfaction with Time Between Request and Receipt of Services........................................... 9

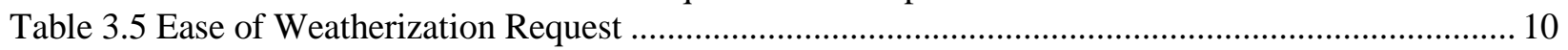

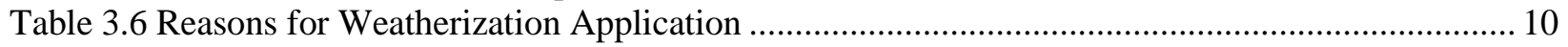

Table 3.7 Actions Taken by the Household Prior to Weatherization ....................................................... 11

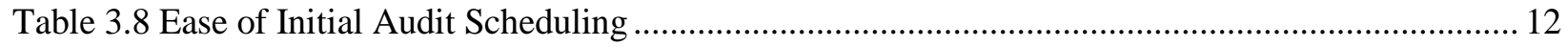

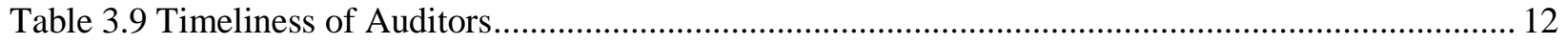

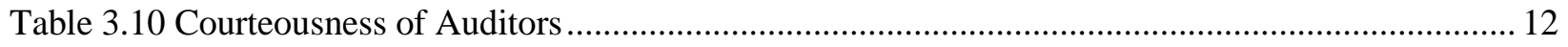

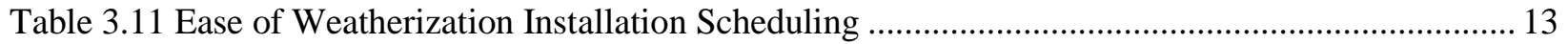

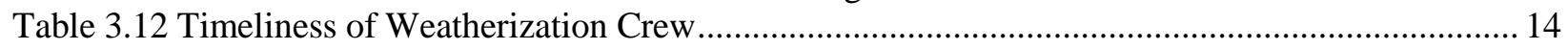

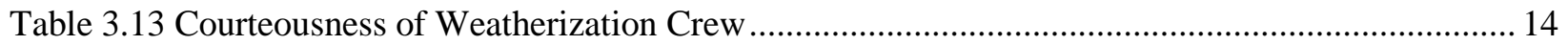

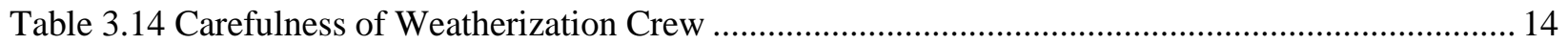

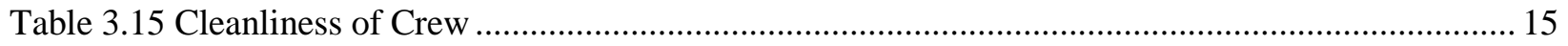

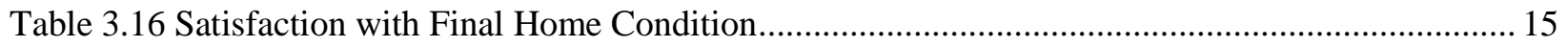

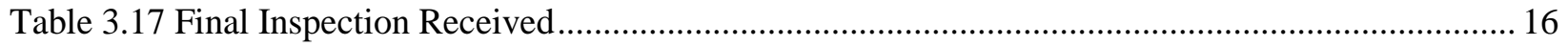

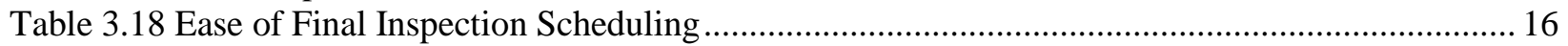

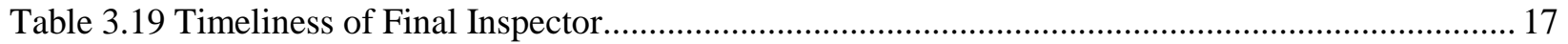

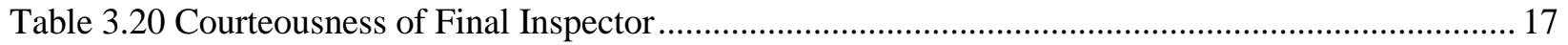

Table 4.1 Information Provided on Ways to Save Energy................................................................ 20

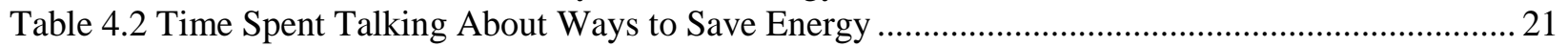

Table 4.3 Understanding of Verbal Information Provided ............................................................... 21

Table 4.4 Staff Provided Educational Materials about Saving Energy ................................................... 22

Table 4.5 Respondent Time Spent Reading or Reviewing Materials about Saving Energy ...................... 22

Table 4.6 Respondent Understanding of Materials about Saving Energy .................................................23

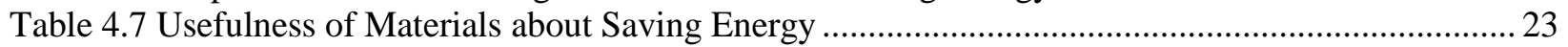

Table 4.8 Useful Features of Materials about Saving Energy .............................................................. 24

Table 4.9 Ways to Improve Materials about Saving Energy ............................................................. 24

Table 4.10 Overall Satisfaction with Energy Saving Information Provided...........................................25

Table 4.11 Staff Knowledge about Health of Household Members .................................................... 25

Table 4.12 Assistance for Household Members in Need of Health Care ............................................... 26

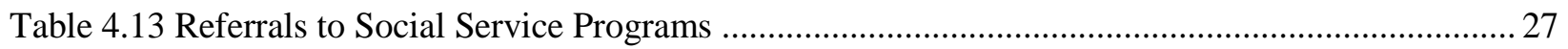

Table 4.14 Staff Provided Information on Ways to Improve Health and Safety in the Home ..................2 27

Table 4.15 Staff Time Spent Talking About Improving Health and Safety ............................................28

Table 4.16 Respondent Understanding of Information on Improving Health and Safety ........................28

Table 4.17 Health and Safety Materials Provided ............................................................................ 29

Table 4.18 Time Reviewed Health and Safety Materials ................................................................... 29

Table 4.19 Respondent Understanding of Materials Provided About Improving Health and Safety ......... 30

Table 4.20 Usefulness of Materials about Improving Health and Safety .................................................30

Table 4.21 Useful Features of the Materials on Improving Health and Safety ......................................... 31

Table 4.22 How Materials on Health and Safety could be Improved ...................................................... 31 


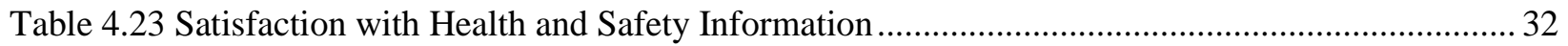

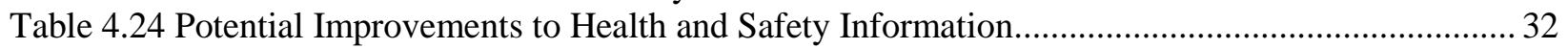

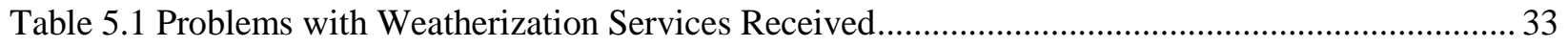

Table 5.2 Complaint Filed about Weatherization Services........................................................................ 34

Table 5.3 Household Perceived Need for Additional Measures .............................................................. 34

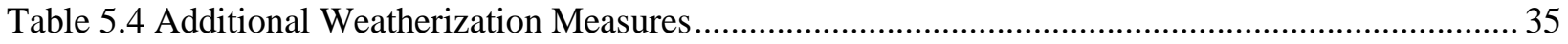

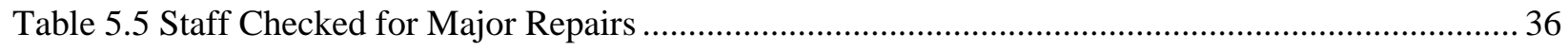

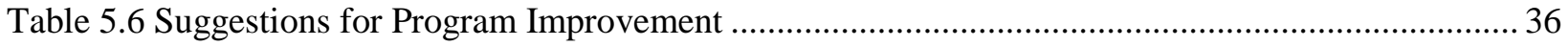

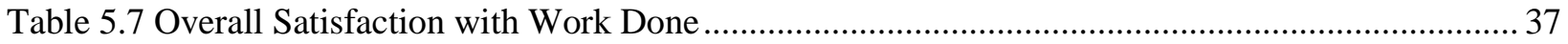

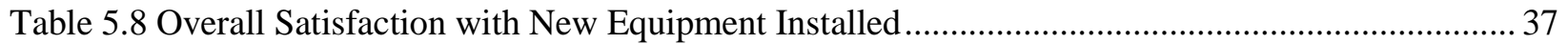

Table 5.9 Satisfaction with Energy Savings after Weatherization........................................................... 38

Table 5.10 Overall Satisfaction with the Weatherization Program.......................................................... 38

Table 5.11 Overall Satisfaction with Key Components of the Program ................................................... 39

Table 5.12 Ease of Dealing with Different Aspects of the Program..........................................................40

Table 5.13 Timeliness of Various Components of the Program ................................................................ 40

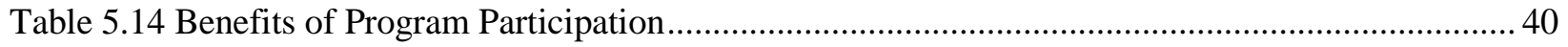

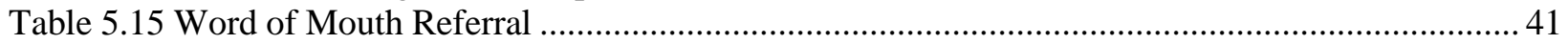

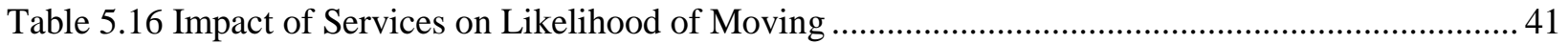

Table 5.17 Likeliness Household Will Move in Next 12 months .......................................................... 42 


\section{ACRONYMS AND ABBREVIATIONS}

$\begin{array}{ll}\text { AC } & \text { Air Conditioning } \\ \text { CATI } & \text { Computer Assisted Telephone Interview } \\ \text { CDD } & \text { Cooling Degree Days } \\ \text { CFL } & \text { Compact Fluorescent Light } \\ \text { CFM50 } & \text { Cubic Feet per Minute @ 50 pascals } \\ \text { CFR } & \text { Code of Federal Regulations } \\ \text { CO } & \text { Carbon Monoxide } \\ \text { DOE } & \text { Department of Energy } \\ \text { ECM } & \text { Energy Conservation Measure } \\ \text { ECW } & \text { Energy Center of Wisconsin } \\ \text { HDD } & \text { Heating Degree Days } \\ \text { KWH } & \text { Kilowatt Hour } \\ \text { LIHEAP } & \text { Low Income Home Energy Assistance Program } \\ \text { MMBTU } & \text { Million British Thermal Units } \\ \text { ORNL } & \text { Oak Ridge National Laboratory } \\ \text { OWIP } & \text { Office of Weatherization and Intergovernmental Programs } \\ \text { PY } & \text { Program Year } \\ \text { RX } & \text { Prescription Medications } \\ \text { SOW } & \text { Scope of Work } \\ \text { SSE } & \text { Steady State Efficiency } \\ \text { TH } & \text { Therm } \\ \text { WAP } & \text { Weatherization Assistance Program } \\ & \end{array}$





\section{ACKNOWLEDGEMENTS}

The work presented in this report was funded by the U.S. Department of Energy's (DOE) Office of Weatherization and Intergovernmental Programs (OWIP).

This report summarizes the findings from the Satisfaction Survey of the Weatherization Assistance Program (WAP) Evaluation. This survey was the second of three surveys conducted with households that received WAP services; it collected information from 665 clients regarding their satisfaction with the services delivered by the program.

The original design for the survey was developed by staff from the Oak Ridge National Laboratory (ORNL) as one component of the National Evaluation of the Weatherization Assistance Program. (National Evaluation of the Weatherization Assistance Program: Preliminary Evaluation Plan for Program 2006 - ORNL/CON-498). As part of the evaluation plan development, the design team consulted with and received feedback from the Network Planning Committee, 41 individuals from the weatherization network. Erin Rose of ORNL developed the final version of the survey instrument.

ORNL contracted with the research team of APPRISE Incorporated, the Energy Center of Wisconsin, Michael Blasnik and Associates, and Dalhoff Associates LLC to conduct the National Evaluation. APPRISE took primary responsibility for the design and implementation of this study. The members of the Evaluation Team who contributed to the design and implementation of this survey included:

\section{APPRISE Incorporated}

Jackie Berger

David Carroll

Colleen Driscoll

Jennifer Frenett

Ferit Ucar

Anne Worth

\author{
The Energy Center of Wisconsin \\ Claire Cowan \\ LaShanta Goodwin \\ Jaimie Rule
}

\section{Carolyn Miller Consulting}

Carolyn Miller

I.C. International prepared the CATI survey instrument, conducted the telephone interviews, and delivered a data file for this study.

This study could only be completed with the cooperation and contributions of the 51 grantees and 220 subgrantees who furnished lists of clients. In addition, the study depended on the willingness of 665 clients to share their experiences with the evaluation team.

Finally, we would like to acknowledge the assistance and guidance of the Oak Ridge National Laboratory, Department of Energy Project Officers, and Department of Energy Headquarters Staff.

Jackie Berger

David Carroll 



\section{EXECUTIVE SUMMARY}

The purpose of this report is to disseminate the findings from an analysis of the WAP Client Satisfaction Survey. The Satisfaction Survey builds on the Baseline Occupant Survey. That survey was conducted in 2011 with two groups of households; one group that applied for WAP services in program year (PY) 2011 (i.e., treatment group) and a second group that had been served by WAP one year earlier in PY 2010 (i.e., comparison group). The Client Satisfaction Survey was conducted with the Baseline Occupant Survey respondents who applied for WAP services in PY 2011 and were served by the program. The primary focus of this survey was to document clients' perceptions of the weatherization program and their satisfaction with the services that they received.

\section{Background}

The U.S. Department of Energy's (DOE) Weatherization Assistance Program was created by Congress in 1976 under Title IV of the Energy Conservation and Production Act. The purpose and scope of the Program as currently stated in the Code of Federal Regulations (CFR) 10 CFR 440.1 is "to increase the energy efficiency of dwellings owned or occupied by low-income persons, reduce their total residential energy expenditures, and improve their health and safety, especially low-income persons who are particularly vulnerable such as the elderly, persons with disabilities, families with children, high residential energy users, and households with high energy burden." (Code of Federal Regulations, 2011)

At the request of DOE, Oak Ridge National Laboratory (ORNL) developed a comprehensive plan for a national evaluation of WAP that was published in 2007. DOE furnished funding to ORNL in 2009 for a national evaluation for Program Years 2007 and 2008, with a particular emphasis on PY 2008. The Scope of Work (SOW) for the evaluation includes an Impact Assessment, a Process Assessment, Special Technical Studies, and a Synthesis Report. The Occupant Surveys contribute to both the Impact and Process Assessments.

\section{Occupant Study Overview}

The Client Satisfaction Survey is one of three surveys conducted with the WAP clients. The Baseline Survey documents status and needs of clients prior to weatherization. The Client Satisfaction Survey collects information on client perceptions of WAP service delivery. The follow-up Occupant Survey directly assesses household budget and energy behaviors pre- to post-weatherization. This is one of several reports that will be completed using findings from the Occupant Surveys. The full set of reports includes:

- Client Satisfaction Survey Report: WAP Service Delivery from the Client's Perspective (Carroll, et al. 2014)

- Baseline Occupant Survey Report: Assessment of Client Status and Needs (Carroll, et al. 2014)

- Survey of Recipients of Weatherization Assistance Program Services: Assessment of Household Budget and Energy Behaviors Pre- to Post-Weatherization (Tonn, et al. 2015)

- Health and Household Related Benefits Attributable to the WAP Program (Tonn, et al. 2014)

- Exploratory Review of State, Agency and Client Experiences with Deferred Services Under the Weatherization Assistance Program (Rose, et al. 2014)

The findings from the Client Satisfaction Survey will contribute to the development of WAP Program Process Evaluation Report. 


\section{Satisfaction Survey Overview and Methodology}

The overarching objective of the Satisfaction Survey is to measure client perceptions about the delivery of weatherization services and the value of the services that they received. The survey topics include:

- Satisfaction with WAP Program Components

- Client Education in the Context of WAP Service Delivery

- Overall WAP Program Satisfaction

In the Baseline Occupant Survey, interviews were completed with 1,094 Treatment Group clients and 803 Comparison Group clients. The Client Satisfaction Survey was conducted with Treatment Group clients. The survey procedures included:

- Client Sample - All Treatment Group respondents were eligible for the survey.

- Round 1 - Three months after the Baseline Survey, Treatment Group respondents were contacted and interviewed if they had received weatherization services. $(\mathrm{N}=418)$

- Round 2 - Nine months after the Baseline Survey, Treatment Group respondents who had not received services after three months were contacted and interviewed if they had received weatherization services by that time. $(\mathrm{N}=247)$

This report focuses on the 665 Treatment Group clients who completed the Satisfaction Survey.

\section{Satisfaction with the Weatherization Process}

When a client receives weatherization services, there are usually four steps in the service delivery process, including:

- Application and Intake - Verification that the household is eligible for the program.

- Audit - Survey of the home to determine which measures would be cost-effective.

- Weatherization Service Delivery - Installation of cost-effective measures.

- Inspection - Verification that measures were installed properly.

In general, the findings from this section show that clients were very satisfied with all aspects of the program service delivery. Weatherization auditors, crews, and inspectors were on time, courteous, and professional. The weatherization crews were careful in their approach to the work and were sure to clean up both inside and outside the home after service delivery.

With respect to the application and intake process, key findings include:

- Application to Service Delivery Interval - The interval between application and service delivery varied considerably for clients; 56 percent of clients were served within one year of application, but 18 percent had to wait two years or more.

- Satisfaction with Interval - Despite the long time interval for some households, clients were satisfied with the process; 84 percent were either satisfied or very satisfied.

- $\quad$ Ease of Weatherization Request - Agencies made the process easy for clients; 87 percent reported that requesting weatherization services was either easy or very easy.

- Reasons for Weatherization Application - Most clients reported that they applied for weatherization to reduce energy bills (78 percent) or make their home more comfortable (67 
percent). Some clients reported that they wanted to support environmental efforts by conserving energy (37 percent).

- Actions Taken Prior to Weatherization - Most clients took actions on their own before receiving weatherization services; 34 percent purchased draft stoppers, 33 percent installed foam tape to stop drafts, and 10 percent repaired or replaced broken windows. Only 19 percent said that they had not done anything.

With respect to the energy audit process, key findings include:

- Ease of Scheduling - Almost all clients (94 percent) said that it was easy or very easy to schedule the home energy audit.

- Timeliness of Auditor - Almost all clients (95 percent) said that the auditor was on time. Only 1 percent of clients reported that the auditor was more than an hour late.

- Courteousness of Auditor - Almost all clients (98 percent) said that the auditor was courteous or very courteous.

With respect to the weatherization measure installation process, key findings include:

- Ease of Scheduling - Almost all clients (93 percent) said that it was easy or very easy to schedule a time for the weatherization crew to come to their home.

- Timeliness of Weatherization Crew - Almost all clients (93 percent) said that the weatherization crew was on time. Only 2 percent of clients reported that the crew was more than an hour late.

- Courteousness of Weatherization Crew - Almost all clients (96 percent) said that the weatherization crew was courteous or very courteous.

- Carefulness of Weatherization Crew - Almost all clients (93 percent) said that the weatherization crew was careful or very careful. Only 1 percent said that the crew was very careless.

- Cleanliness of Weatherization Crew - Most clients (89 percent) said that the weatherization crew left their home clean. Only 3 percent reported that the crew left their home dirty.

- Final Condition of Home - Almost all clients (93 percent) said that they were satisfied or very satisfied with the final condition of their home. 
With respect to the final inspection process, key findings include:

- Ease of Scheduling - Almost all clients (97 percent) said that it was easy or very easy to schedule the final inspection.

- Timeliness of Auditor - Almost all clients (97 percent) said the inspector was on time. Less than 1 percent of clients reported that the inspector was more than an hour late.

- Courteousness of Auditor - Almost all clients (97 percent) said that the inspector was courteous or very courteous.

The weatherization process - conducting audits, delivering weatherization services, and conducting final inspections - can be challenging to schedule and complicated to complete effectively. However, these high grades (90 percent or above on almost all measures) speak well of the systems that the weatherization network has put in place to deliver these services.

\section{Client Education}

The Satisfaction Survey asked clients to describe the extent to which the program furnished information on energy efficiency and health and safety, and to report on their satisfaction with those components of the program.

The survey found that most, but not all, clients received energy education services. When they received services, the clients generally reported that the information was useful. However, compared to the investment in installation of energy efficiency measures and resolution of health and safety problems, the investment in direct energy education was modest and did not appear to have a major impact on the client's weatherization experience. Most clients reported that they had less than 30 minutes of energy education. Some key findings with respect to energy education include:

- Incidence - 69 percent of clients reported that they received some information from weatherization staff on ways to save energy in their home.

- Intensity - 22 percent of clients reported that staff spent 30 minutes or more talking to them about ways to save energy. The median amount of time was 14 minutes.

- Quality -96 percent of clients who received energy education said that they understood the information either well or very well.

- Materials - 50 percent of clients reported that they received some educational materials on saving energy.

- Material Review - 70 percent of clients who received energy education materials spent 15 minutes or more reviewing the materials.

- Material Quality - 96 percent of clients who received energy education materials said that they understood the materials either well or very well.

- Overall Satisfaction - 94 percent of the clients who received energy education reported that they were either satisfied or very satisfied with the information.

The survey found that less than half of the weatherization clients reported that they had significant interactions with the weatherization program staff in terms of health and safety issues. Among those clients who had in-depth discussions about health and safety issues, it is clear that the clients understood some important messages about how to protect their health and the health of their families, both in terms of the safety of energy efficiency equipment and in terms of the impact of other factors on the indoor air quality in their homes. However, the service delivery process did not focus as much on health and safety as it did on energy efficiency. Some key findings with respect to health and safety education include: 
- Health Status - 50 percent of clients reported that they were either asked about health issues by weatherization staff or they volunteered information on health issues to the weatherization staff.

- Unmet Health Needs - Only 5 percent of clients who reported on health status indicated that there was at least one household member with unmet healthcare needs.

- Referrals - 11 percent of clients reported that weatherization staff referred them to social service programs; however, most of the referrals were to cash or in-kind assistance programs rather than health programs.

- Health and Safety Education - 40 percent of clients reported that weatherization staff furnished information on ways to improve health and safety in their home.

- Intensity - Clients who received information talked to weatherization staff for an average of 20 minutes.

- Quality -98 percent of clients who received health and safety education said that they understood the information either well or very well.

- Materials - 24 percent of clients reported that they received some educational materials on health and safety.

- Material Review - Clients who received health and safety education materials spent an average of 15 minutes reviewing the materials.

- Material Quality - 96 percent of clients who received health and safety education materials said that they understood the materials either well or very well.

- Overall Satisfaction - 95 percent of the clients who received health and safety education reported that they were either satisfied or very satisfied with the information.

These findings might suggest that the program could do more client education, particularly for health and safety issues. However, the survey only tells us about the experience of clients, not the reason for those experiences. With respect to energy efficiency education, many service delivery professionals suggest that they can be more useful by engaging clients in the weatherization process, rather than by talking about savings practices independent of the installed measures. In terms of health and safety education, service delivery staff may only focus on these issues for homes and households where there clearly is a problem. In both the Baseline Survey and in the Satisfaction Survey, most clients did not report any major health issues or safety concerns. One possible interpretation of the results is that service delivery staff are responding to education opportunities, rather than conducting education with every client.

Overall, many clients receive energy education and some clients receive health and safety education. While most clients seem satisfied with the services, it is not clear that they see this as a major benefit of the program. And, it does not seem like there has been a significant investment in terms of the time spent on education. The findings from this survey suggest that client education in the program is treated as a service that supports the weatherization process, rather than being a major focus of the program. If policymakers perceive that either energy education or health and safety education can deliver major benefits to low-income households, it seems that some change in either the delivery of those services or in the program guidance would be required to achieve that level of benefit.

\section{Overall Program Satisfaction}

The Satisfaction Survey shows that the Weatherization Assistance Program gets high marks from clients; over 90 percent of clients are satisfied or very satisfied with most aspects of service delivery. But, it is useful to consider where clients give the program the highest rating - "very satisfied" - compared to those program elements where they are more likely to say that they are "satisfied." This offers some insight on where there is some room for improvement. Table 1 shows that the program gets consistently high marks 
for the final conditions inside and outside the home, the work performed, the new equipment, and the overall program. The areas where clients were less likely to report that they are very satisfied are information on health and safety measures, information on saving energy, and the length of time between the request for weatherization and the time when the home was weatherized. Clients gave a lower rating to the level of energy savings in the home, but that may be partially because, for many clients, not enough time had passed to observe the level of energy savings.

Table 1 Overall Satisfaction with Key Components of the Program

\begin{tabular}{|c|c|c|}
\hline \multicolumn{3}{|l|}{ How satisfied are you with the ___ ? } \\
\hline Number of Respondents & Very Satisfied (665) & Satisfied (665) \\
\hline $\begin{array}{l}\text { Length of time between request to have home weatherized and when } \\
\text { it was weatherized }\end{array}$ & $44 \%$ & $39 \%$ \\
\hline Final condition of the inside of the home & $58 \%$ & $35 \%$ \\
\hline Final condition of the outside of the home & $59 \%$ & $33 \%$ \\
\hline Work performed in the home & $60 \%$ & $33 \%$ \\
\hline New equipment installed in the home & $61 \%$ & $30 \%$ \\
\hline Energy savings achieved after having the home weatherized & $35 \%$ & $22 \%$ \\
\hline Information on saving energy & $37 \%$ & $28 \%$ \\
\hline Information on improving health and safety & $22 \%$ & $16 \%$ \\
\hline Overall Weatherization Program & $63 \%$ & $31 \%$ \\
\hline
\end{tabular}

The survey also showed that the program got high ratings in terms of client service. Table 2 shows that almost all clients found that it was easy or very easy to schedule work and Table 3 shows that almost all of the professionals who came to the home were either early or on time.

Table 2 Ease of Dealing with Different Aspects of the Program

\begin{tabular}{|c|c|c|c|}
\hline \multicolumn{4}{|l|}{ How easy was it to ___ ? } \\
\hline & Respondents & Very Easy & Easy \\
\hline Request that the home be weatherized & 657 & $40 \%$ & $47 \%$ \\
\hline Schedule the initial audit & 660 & $49 \%$ & $45 \%$ \\
\hline Schedule the weatherization crew to come to home & 661 & $53 \%$ & $40 \%$ \\
\hline Schedule the final inspection & 502 & $62 \%$ & $35 \%$ \\
\hline
\end{tabular}

Table 3 Timeliness of Various Components of the Program

\begin{tabular}{|l||c||c||}
\hline \hline How timely was/were & Respondents & $\begin{array}{c}\text { Percent who said } \\
\text { 'early or on time' }\end{array}$ \\
\hline \hline The people who did the initial audit of the home & 651 & $95 \%$ \\
\hline The weatherization crew & 658 & $93 \%$ \\
\hline The people who did the final inspection of the home & 501 & $97 \%$ \\
\hline
\end{tabular}


The Satisfaction Survey showed that clients clearly understand the benefits for the program. Clients perceive that:

- Their homes use less energy

- Their homes are more comfortable

- Their homes have better energy equipment

- They are now less likely to have to move from their home

The survey also showed that clients tell other low-income households about the program and that some of those households get weatherized. It is hard to have a better testimonial regarding the value of the program to low-income households and their satisfaction with program services than the direct and obviously compelling recommendation to their friends and neighbors. 



\section{INTRODUCTION}

The purpose of this report is to disseminate the findings from an analysis of the WAP Client Satisfaction Survey. It is one of three surveys conducted with households that received WAP services. The Baseline Survey documents status and needs of clients prior to weatherization. The Satisfaction Survey collects information on client perceptions of WAP service delivery. The follow-up Occupant Survey directly assesses household budget and energy behaviors pre- to post-weatherization.

This is one of several reports that will be completed using findings from the Occupant Surveys. The full set of reports includes:

- Client Satisfaction Survey Report: WAP Service Delivery from the Client's Perspective (Carroll, et al. 2014)

- Baseline Occupant Survey Report: Assessment of Client Status and Needs (Carroll, et al. 2014)

- Survey of Recipients of Weatherization Assistance Program Services: Assessment of Household Budget and Energy Behaviors Pre- to Post-Weatherization (Tonn, et al. 2015)

- Health and Household Related Benefits Attributable to the WAP Program (Tonn, et al. 2014)

- Exploratory Review of State, Agency and Client Experiences with Deferred Services Under the Weatherization Assistance Program (Rose, et al. 2014)

The Client Satisfaction Survey Report and the Deferral Report contribute to the WAP Program Process Report.

\subsection{NATIONAL WEATHERIZATION ASSISTANCE PROGRAM EVALUATION OVERVIEW}

The U.S. Department of Energy's (DOE) Weatherization Assistance Program was created by Congress in 1976 under Title IV of the Energy Conservation and Production Act. The purpose and scope of the Program as currently stated in the Code of Federal Regulations (CFR) 10CRF 440.1 is "to increase the energy efficiency of dwellings owned or occupied by low-income persons, reduce their total residential energy expenditures, and improve their health and safety, especially low-income persons who are particularly vulnerable such as the elderly, persons with disabilities, families with children, high residential energy users, and households with high energy burden." (Code of Federal Regulations, 2011)

At the request of DOE, Oak Ridge National Laboratory (ORNL) developed a comprehensive plan for a national evaluation of WAP that was published in 2007. (National Evaluation of the Weatherization Assistance Program: Preliminary Evaluation Plan for Program Year 2006, February 2007) DOE furnished funding to ORNL in 2009 for a national evaluation for Program Years 2007 and 2008, with a particular emphasis on PY 2008. ORNL subcontracted evaluation research to APPRISE Incorporated and its partners (the Energy Center of Wisconsin, Michael Blasnik and Associates, and Dalhoff Associates LLC). The Scope of Work (SOW) for the evaluation includes the following components.

- Impact Assessment - Characterization of the weatherization network and the households that are income-eligible for WAP. Measurement and monetization of the energy and nonenergy impacts of the program. Assessment of the factors associated with higher levels of energy savings, cost savings, and cost-effectiveness.

- Process Assessment - Direct observation of how the weatherization network delivers services and assessment of how service delivery compares to national standards. Documentation of how weatherization staff and clients perceive service delivery. 
- Special Technical Studies - Examination of the performance of the program with respect to technical issues such as air sealing, duct sealing, furnace efficiency, and refrigerators.

- Synthesis Study - Synthesis of the findings from this evaluation into a comprehensive assessment of the success of the program in meeting its goals and identification of key areas for program enhancement.

The Occupant Surveys contribute to both the Impact Assessment and the Process Assessment. WAP program non-energy benefits will be measured for the Impact Assessment by comparing the preweatherization status of WAP clients in the Baseline Survey to the post-weatherization status of WAP clients in the Follow-Up Survey. WAP client perceptions will be measured for the Process Assessment through the Client Satisfaction Survey. WAP procedures with respect to deferral of clients will be measured for the Process Assessment through the Follow-Up survey with deferred clients.

\subsection{SATISFACTION SURVEY STUDY OVERVIEW}

The overarching objective of the Satisfaction Survey is to measure client perceptions about the delivery of weatherization services and the value of the services that they received. The survey topics include:

- Satisfaction with WAP Program Components

- Client Education in the Context of WAP Service Delivery

- Overall WAP Program Satisfaction

The Satisfaction Survey was conducted with the respondents to the Baseline Occupant Survey who applied for WAP in PY 2011. The sample for the Baseline Occupant Survey included households that had applied for WAP services, were determined to be income-eligible for the program, and were scheduled for a home energy audit during PY 2011. The households were interviewed prior to receiving their home energy audit. The first round of the Satisfaction Survey was conducted three months after the Baseline interview. If the respondent had received services, they were interviewed. If a respondent had not yet received services, their interview was deferred. The second round of the Satisfaction Survey was conducted nine months after the Baseline Interview. If a respondent had received services, they were interviewed. If a respondent had not received services, they were asked about their perceptions of why WAP services were not delivered and were included in the sample for the Deferral Survey.

\subsection{ORGANIZATION OF THE CLIENT SATISFACTION SURVEY REPORT}

This report consists of five sections, including:

- Section 1 - Introduction: Furnishes an overview of the Weatherization Assistance Program Evaluation and the purpose of the Client Satisfaction Survey.

- Section 2 - Survey Design and Implementation: Outlines the Satisfaction Survey sampling and data collection procedures.

- Section 3 - Satisfaction with WAP Program Components: Examines information on WAP clients' initial program awareness and experience with different phases of the program.

- Section 4-Client Education in the Context of WAP Service Delivery: Analyzes what information clients retained on energy saving behaviors, and health and safety practices from the WAP visits.

- Section 5 - Overall WAP Program Satisfaction: Provides statistics of clients' overall satisfaction with the program, their perception of program benefits, and their suggestions for improvement.

These findings are for a representative national sample of clients served in PY 2011. 


\section{SURVEY DESIGN AND IMPLEMENTATION}

The Client Satisfaction Survey is one of three surveys that are planned to be conducted with the selected WAP clients. The Baseline Survey documented status and needs of clients prior to weatherization. The Satisfaction Survey collected information on client perceptions of the WAP program and WAP service delivery. The Follow-Up Survey will measure how the status and needs of clients have changed one year after receiving WAP services.

\subsection{SATISFACTION SURVEY METHODOLOGY}

The initial survey procedures for the Baseline Occupant Survey included the following:

- Agency Sample - A sample of 220 service delivery agencies was selected to represent the 905 WAP service agencies nationwide.

- Treatment Group Sample - Each agency was asked to furnish a list of clients who was incomequalified for the program and that was scheduled for a WAP audit.

- Comparison Group Sample - Each agency was asked to furnish a list of clients who received WAP services one year earlier.

- Interviews - Sampled treatment and comparison group clients were contacted and interviewed using a survey instrument designed by the ORNL Evaluation Team.

Interviews were completed with 1,094 treatment group clients and 803 comparison group clients.

The survey procedures for the Client Satisfaction Survey included the following:

- Client Sample - All Treatment Group survey respondents $(n=1,094)$ were eligible for the Satisfaction Survey.

- Round 1 - Three months after the completion of the Baseline Survey field period, Treatment Group survey respondents were contacted and screened using a survey instrument designed by the ORNL Evaluation Team. If the survey respondent had received weatherization services, they were interviewed. If they had not received weatherization services, their interview was deferred. 418 Baseline Survey respondents were interviewed in Round 1 of the Client Satisfaction Survey.

- Round 2 - Nine months after the completion of the Baseline Survey field period, deferred Treatment Group survey respondents were contacted and screened using a survey instrument designed by the ORNL Evaluation Team. If the survey respondent had received weatherization services, they were interviewed. 247 Baseline Survey respondents were interviewed in Round 2 of the Client Satisfaction Survey. If the survey respondent had not received weatherization services, they were asked questions related to service deferral.

- Survey Statistics - In total, 665 of the Treatment Group clients received WAP services, continued to live in the weatherized housing unit, and could be contacted for follow-up interviews. Those Baseline Survey respondents completed the Satisfaction Survey interview. Among the 1,094 treatment group clients surveyed prior to receiving a WAP audit, 290 reported that they had not received WAP services and 139 could no longer be reached by telephone.

This report will focus on the 665 Treatment Group clients who completed the Client Satisfaction Survey interview. 


\subsection{ANALYSIS FRAMEWORK}

The primary purpose of the Occupant Surveys is to furnish information on the energy status and needs of applicant households and to assess the extent to which the WAP program is able to address those needs. The primary analysis sample for the study is the treatment group; households that have applied for the WAP program, have been determined to be income qualified for the program, and were scheduled for a WAP home energy audit. This study is designed to:

- Develop an understanding of their energy status and needs prior to any significant contact with the program,

- Determine whether the WAP program was able to deliver services to them,

- Assess their perceptions of the effectiveness of the WAP program in meeting their needs, and

- Measure the change in status and needs of the household after having received WAP services.

The three surveys contribute to this analysis in the following way.

- Baseline Survey - The Baseline Survey was conducted with WAP clients prior to their home energy audit. While clients may have had some engagement with the WAP program by applying for program services, these interviews represent, as much as possible, the needs of the applicant households prior to receiving services from the WAP program.

- Client Satisfaction Survey - The Client Satisfaction Survey was conducted with households that received WAP services. It collected information on client perceptions of the WAP program and WAP service delivery.

- Follow-Up Survey - The Follow-Up Survey is planned to be conducted at the end of the winter of 2012-2013. The survey will be conducted with all treatment group households, including those that were served and those that were deferred. It shows how the status of households changed after receipt of WAP program services.

One important component of the research design for the Baseline and Follow-Up Surveys is that a comparison group of WAP clients was interviewed. The treatment group households were scheduled to receive WAP services during PY 2011. A comparison group of households that received services during PY 2010 also was sampled and interviewed. The primary purpose of the comparison group is to furnish a "difference of differences" analysis. In such a design, the gross program impact is the change in the treatment group status. But, the net program impact is determined by measuring the status change for a comparison group and netting out any change for the comparison group against the change for the treatment group to control for other unobserved factors.

Since the primary focus of the Satisfaction Survey is to ascertain client perceptions of weatherization services and the weatherization program a net difference analysis is not needed. Therefore, the Satisfaction Survey did not include the comparison group households.

\subsection{DATA COLLECTION STATISTICS}

The Client Satisfaction Survey used sample development and interviewing procedures that were designed to achieve the highest possible response rate. The Satisfaction Survey Sample came from the treatment group households that responded to the Baseline Occupant Survey.

The original agency contacts for the Occupant Surveys were made by Energy Center of Wisconsin (ECW) case managers who have been working with service delivery agencies since 2010 to facilitate data collection for the overall evaluation project. For each sampled service delivery agency: 
- Advance Mailing - The ECW case manager mailed information to the agency contact explaining the purpose of the data collection and the procedures for selecting and delivering client lists.

- Agency Phone Contact - The ECW case manager contacted the agency contact to discuss the data collection schedule and to clarify the study procedures.

- Agency Follow-Up - The ECW case manager conducted regular follow-up with the agency contact to facilitate the development and delivery of the clients lists.

Of the 220 sampled agencies, 204 (93\%) furnished client lists. The survey was successful in getting completed interviews from 203 of the 204 agencies that furnished client lists.

The Baseline Occupant Survey implementation procedures included:

- Advance Mailing - Sampled households were sent a letter that alerted them that they would be contacted by Braun Research, described the purpose of the survey, furnished a call-in 800 number that would allow them to do the survey at their convenience, and notified them that they would receive a $\$ 20$ incentive for completing the interview.

- Phone Contact - Braun Research made at least 12 call attempts to each household at different times of the day and on different days of the week. On the first call attempt, and every third call attempt thereafter, interviewers left messages on answering machines.

- Refusal Conversion - If a potential respondent refused to conduct the interview, they were called back by a refusal conversion team that attempted to address any concerns about completing the interview.

- Spanish Language Interviews - When the telephone center encountered Hispanic households with a language barrier, an interviewer re-contacted the households and conducted the interview in Spanish.

Interviewers completed 1,094 Baseline Occupant Survey interviews with Treatment Group households with an estimated response rate of $73 \%$.

The Treatment Group respondents were eligible for the Client Satisfaction Survey. The survey implementation procedures included:

- Advance Mailing - Sampled households were sent a letter that alerted them that they would be contacted by IC International, described the purpose of the survey, furnished a call-in 800 number that would allow them to do the survey at their convenience, and notified them that they would receive a $\$ 10$ incentive for completing the interview.

- Phone Contact - IC International made at least 12 call attempts to each household at different times of the day and on different days of the week. On the first call attempt, and every third call attempt thereafter, interviewers left messages on answering machines.

- Refusal Conversion - If a potential respondent refused to conduct the interview, they were called back by a refusal conversion team that attempted to address any concerns about completing the interview.

- Spanish Language Interviews - When the telephone center encountered Hispanic households with a language barrier, an APPRISE interviewer re-contacted the households and conducted the interview in Spanish.

Interviewers completed 665 Client Satisfaction Survey interviews with an estimated response rate of $87 \%$. 



\section{SATISFACTION WITH THE WEATHERIZATION PROCESS}

This section of the report provides findings on respondents' initial awareness of the program and their program experiences. The section is divided into four sub-sections that look at each step in the service delivery process, including:

- Application and Intake

- Audit

- Weatherization Service Delivery

- Final inspection

In general, the findings from this section show that clients were very satisfied with all aspects of the program service delivery. Weatherization auditors, crews, and inspectors were on time, courteous, and professional. The weatherization crews were careful in their approach to the work and cleaned up both inside and outside the home after service delivery.

\subsection{APPLICATION AND INTAKE}

The first part of the Client Satisfaction Survey asked respondents to report on their experiences with application and intake, including:

- How and when the respondent first learned of the program

- How long it took between request for and receipt of services

- Satisfaction with timeliness of services

- Ease of request for services

- Why the respondent applied

- Weatherization actions taken prior to program participation

In reviewing the responses furnished by clients in this section, it is important to consider two important factors associated with how clients experience program application and intake.

- First, a client's application and intake experience is likely to vary depending on how they were referred to the program; the experience for a direct Low Income Home Energy Assistance Program (LIHEAP) referral may be quite different than from the experience for a household that learned of the WAP program from other sources, had to apply for the program, and had to furnish information to qualify for the program.

- Second, the experiences of clients during the ARRA funding period of the program may be different from the experiences of clients who applied for and were served prior to the ARRA funding period.

From those perspectives, the Client Satisfaction Survey furnishes useful information about the application and intake experiences of clients during the ARRA period, but may not be applicable to client experiences during other program years.

Table 3.1 shows that about 14 percent of the respondents knew about the program for less than one year, 19 percent for one year, 17 percent for two years, and 43 percent for three or more years. This shows that, even during the ARRA period, many clients were familiar with the WAP program a long time before they received WAP services. 
Table 3.1 Awareness of Local Weatherization Program

\begin{tabular}{|l||c||}
\hline How long have you known about your local weatherization program? & 665 \\
\hline \hline Number of Respondents & $5 \%$ \\
\hline \hline Less than 6 months & $9 \%$ \\
\hline 1 year & $19 \%$ \\
\hline 2 years & $17 \%$ \\
\hline $3-5$ years & $20 \%$ \\
\hline 6 or more years & $23 \%$ \\
\hline Don't Know & $6 \%$ \\
\hline \hline TOTAL & $100 \%$ \\
\hline \hline
\end{tabular}

Respondents were asked an open-ended question about how they first learned about the local weatherization program. Table 3.2 shows that clients were most likely to learn about the program from family or friends ( 37 percent), and next most likely from the local agency ( 22 percent). Other common methods were social services, the local media, a letter or flyer, or a neighbor who received services.

Table 3.2 How Learned about Local Weatherization Program

\begin{tabular}{|l|c||}
\hline How did you find out about your local weatherization program $?^{1}$ & 641 \\
\hline \hline Number of Respondents & $37 \%$ \\
\hline \hline Relative or friend mentioned the weatherization program & $22 \%$ \\
\hline Agency providing utility assistance, such as LIHEAP & $13 \%$ \\
\hline Social services/senior program & $9 \%$ \\
\hline Local newspaper or other local media & $8 \%$ \\
\hline Letter/flyer & $7 \%$ \\
\hline Neighbor who had their home weatherized & $3 \%$ \\
\hline Utility company/fuel supplier & $2 \%$ \\
\hline A call from the weatherization agency & $2 \%$ \\
\hline Found the program on the internet & $1 \%$ \\
\hline Church & $5 \%$ \\
\hline Other & \\
\hline
\end{tabular}

Table 3.3 shows that most households had to wait to have their homes weatherized. Even during the ARRA period, about 40 percent of households waited at least one year to have their home audited, and about 15 percent waited at least two years.

\footnotetext{
${ }^{1}$ Respondents could choose more than one response.
} 
Table 3.3 Time Since First Request for Weatherization

\begin{tabular}{||l||c||}
\hline How long ago did you first request that your home be weatherized? & 661 \\
\hline \hline Number of Respondents & $28 \%$ \\
\hline \hline$<6$ months & $22 \%$ \\
\hline 1 year & $23 \%$ \\
\hline 2 years & $6 \%$ \\
\hline 3 or more years & $10 \%$ \\
\hline Don't Know & $11 \%$ \\
\hline \hline TOTAL & $100 \%$ \\
\hline \hline
\end{tabular}

Considering that many households waited one year or more to receive services, it is surprising that client satisfaction with the waiting period was so high (Table 3.4). Only eight percent of clients were dissatisfied with the time between the request and the receipt of services, while 44 percent reported that they were very satisfied.

Table 3.4 Satisfaction with Time Between Request and Receipt of Services

\begin{tabular}{|l|c|}
\hline $\begin{array}{l}\text { How satisfied are you with the length of time between your request to have your home weatherized and when it } \\
\text { actually was weatherized? }\end{array}$ & 663 \\
\hline \hline Number of Respondents & $44 \%$ \\
\hline \hline Very satisfied & $40 \%$ \\
\hline Satisfied & $8 \%$ \\
\hline Neither satisfied nor dissatisfied & $6 \%$ \\
\hline Dissatisfied & $2 \%$ \\
\hline Very dissatisfied & $100 \%$ \\
\hline \hline TOTAL & 2 \\
\hline
\end{tabular}

Clients reported that it was easy to request weatherization services. These findings are presented in Table 3.5. Forty percent said it was very easy to request that their home be weatherized and another 47 percent said it was easy. Since many households are referred directly from the LIHEAP program to the WAP program, this result is not unexpected. 
Table 3.5 Ease of Weatherization Request

\begin{tabular}{|l|c|}
\hline \hline How easy was it to request that your house be weatherized? & 657 \\
\hline \hline Number of Respondents & $40 \%$ \\
\hline \hline Very easy & $47 \%$ \\
\hline Easy & $6 \%$ \\
\hline Neither easy nor difficult & $6 \%$ \\
\hline Difficult & $1 \%$ \\
\hline Very difficult & $100 \%$ \\
\hline \hline TOTAL & \multicolumn{2}{|c|}{} \\
\hline
\end{tabular}

Table 3.6 presents information on the reasons clients provided for applying to the weatherization program. Respondents could select more than one response to this question and could volunteer additional reasons. The two most commonly mentioned reasons were to reduce energy bills (78 percent) and to improve the comfort of their home (67 percent). Far less common reasons, mentioned by about half as many clients, were environmental reasons and the opportunity to receive free services.

Table 3.6 Reasons for Weatherization Application

\begin{tabular}{|c|c|}
\hline \multicolumn{2}{|c|}{ Why did you apply for the Weatherization Assistance Program? $?^{2}$} \\
\hline Number of Respondents & 660 \\
\hline Reduce energy bills & $78 \%$ \\
\hline Make home more comfortable & $67 \%$ \\
\hline Support environmental efforts to conserve energy & $37 \%$ \\
\hline Receive free services & $34 \%$ \\
\hline Improve health and/or safety (volunteered) & $2 \%$ \\
\hline Other & $2 \%$ \\
\hline
\end{tabular}

Table 3.7 shows that prior to receiving weatherization services more than 80 percent of clients took one or more actions to weatherize their home. The most common actions were low-cost items such as putting draft stoppers on windows or doors, or using some material to stop drafts. However, some clients took more extensive actions; 10 percent replaced or repaired roofs, furnaces, and doors or windows. Another 9 percent installed insulation. About one in five households reported that they had not done anything.

\footnotetext{
${ }^{2}$ Respondents could provide more than one response for this question.
} 
Table 3.7 Actions Taken by the Household Prior to Weatherization

\begin{tabular}{|l|c||}
\hline \multicolumn{2}{|l||}{ Prior to receiving weatherization services, in what ways did your household attempt to weatherize your home ${ }^{3}$} \\
\hline \hline Number of Respondents & 665 \\
\hline \hline Installed draft stoppers on doors or windows & $34 \%$ \\
\hline Used foam tape (or other material) to stop draft & $33 \%$ \\
\hline Engaged in energy efficient behaviors & $11 \%$ \\
\hline Replace or repaired roof/door/windows/appliances & $10 \%$ \\
\hline Added insulation & $9 \%$ \\
\hline Replaced or repaired broken windows & $8 \%$ \\
\hline Caulked holes and/or leaks & $8 \%$ \\
\hline Put in insulation around a/c or heating ducts & $4 \%$ \\
\hline Reduced heat/used space heaters & $4 \%$ \\
\hline Did not do anything & $19 \%$ \\
\hline Other & $7 \%$ \\
\hline Don't Know & $5 \%$ \\
\hline \hline
\end{tabular}

Overall, clients seemed to have a good understanding of the weatherization program and realistic expectations of the weatherization outcomes. Even though they had to wait a long time for program services, they reported being satisfied with the application and intake procedures.

\subsection{AUDIT}

When an agency is ready to weatherize a home, they start the process by conducting an audit of the client's home. In an audit, the agency sends an energy expert to interview the client, inspect the home, and conduct tests to assess what energy efficiency measures would be cost-effective. In addition, many agencies use this time in the home to educate clients about ways that they can save energy through behavioral changes.

This section presents respondents' views on the following aspects of the audit.

- $\quad$ Ease of scheduling

- Timeliness of auditors

- Courteousness of auditors

Almost all clients reported satisfaction with these aspects of the audit. Over 90 percent of clients reported that it was very easy or easy to schedule the initial audit (Table 3.8), 95 percent reported that the auditor was either early or on time (Table 3.9), and 98 percent them reported that the auditor was courteous or very courteous (Table 3.10). These are high levels of satisfaction for service delivery professionals.

\footnotetext{
${ }^{3}$ Respondents could provide more than one response for this question.
} 
Table 3.8 Ease of Initial Audit Scheduling

\begin{tabular}{|l|c||}
\hline How easy was it to schedule the initial audit of your home? & 660 \\
\hline Number of Respondents & $49 \%$ \\
\hline \hline Very easy & $45 \%$ \\
\hline Easy & $3 \%$ \\
\hline Neither easy nor difficult & $3 \%$ \\
\hline Difficult & $1 \%$ \\
\hline Very difficult & $100 \%$ \\
\hline \hline TOTAL & \\
\hline
\end{tabular}

Table 3.9 Timeliness of Auditors

\begin{tabular}{|l||c||}
\hline How timely were the people who did the initial audit of your home? & 651 \\
\hline Number of Respondents & $95 \%$ \\
\hline \hline Early or on time & $2 \%$ \\
\hline Less than 30 minutes late & $1 \%$ \\
\hline $30-59$ minutes late & $1 \%$ \\
\hline 1 to 3 hours late & $<1 \%$ \\
\hline More than 3 hours late & $<1 \%$ \\
\hline Did not show up on scheduled day & $100 \%$ \\
\hline \hline TOTAL & \\
\hline
\end{tabular}

Table 3.10 Courteousness of Auditors

\begin{tabular}{|l|c|}
\hline How courteous were the people who did the initial audit of your home? & 660 \\
\hline \hline Number of Respondents & $81 \%$ \\
\hline \hline Very courteous & $17 \%$ \\
\hline Courteous & $2 \%$ \\
\hline Neither courteous nor rude & $<1 \%$ \\
\hline Rude & $0 \%$ \\
\hline Very rude & $100 \%$ \\
\hline \hline TOTAL & $2 \%$ \\
\hline
\end{tabular}

\subsection{WEATHERIZATION SERVICES}

If the auditor determines that there are weatherization measures that have a savings to investment ratio (SIR) of 1.0 or greater, and that there are no barriers to installing the needed measures (e.g., structural problems), the agency works with the client to schedule a time to deliver weatherization services. The service delivery phase may take as little as one day on site, or as much as one week. In addition, certain measures may be installed by other contractors and may need to be scheduled at a different time. For example, not all weatherization agencies are qualified to install a new furnace and that measure may be 
scheduled by a heating contractor. Each client is likely to have a somewhat different experience with the delivery of weatherization services. Therefore, any observed variation in client satisfaction may relate to differential performance, but also may relate to the types of measures installed.

This section presents respondents' views on aspects of weatherization service delivery.

- $\quad$ Ease of scheduling services

- $\quad$ Timeliness of crew

- $\quad$ Courteousness, care, and cleanliness of the crew

- $\quad$ Satisfaction with condition of the home after services

Table 3.11 shows that 53 percent of clients said it was very easy to schedule a time for the weatherization crew to come to their home. An additional 40 percent said it was easy. Less than three percent found this process difficult or very difficult.

Table 3.11 Ease of Weatherization Installation Scheduling

\begin{tabular}{|l|c|}
\hline How easy was it to schedule the time for the weatherization crew to come to your home? \\
\hline \hline Number of Respondents & 661 \\
\hline \hline Very easy & $53 \%$ \\
\hline Easy & $40 \%$ \\
\hline Neither easy nor difficult & $5 \%$ \\
\hline Difficult & $2 \%$ \\
\hline Very difficult & $<1 \%$ \\
\hline \hline TOTAL & $100 \%$ \\
\hline
\end{tabular}

Weatherization crew were rated very well on timeliness, as shown in Table 3.12. Ninety-three percent said the crew was either on time or early and three percent said they were less than 30 minutes late. Less than five percent reported that the crew was 30 minutes late or more. 
Table 3.12 Timeliness of Weatherization Crew

\begin{tabular}{|l||c||}
\hline How timely was the weatherization crew? & 658 \\
\hline \hline Number of Respondents & $93 \%$ \\
\hline \hline Early or on time & $3 \%$ \\
\hline$<30$ minutes late & $2 \%$ \\
\hline $30-59$ minutes late & $1 \%$ \\
\hline $1-3$ hours late & $1 \%$ \\
\hline$>3$ hours late & $<1 \%$ \\
\hline Did not show up on scheduled day & $100 \%$ \\
\hline \hline TOTAL & 2 \\
\hline \hline
\end{tabular}

Table 3.13 shows that the weatherization crew was perceived as very courteous by the majority of clients. Seventy-three percent said they were very courteous and 23 percent said they were courteous. Less than one percent found them rude.

Table 3.13 Courteousness of Weatherization Crew

\begin{tabular}{|l|r||}
\hline How courteous was the weatherization crew? & 660 \\
\hline \hline Number of Respondents & $73 \%$ \\
\hline \hline Very courteous & $23 \%$ \\
\hline Courteous & $3 \%$ \\
\hline Neither courteous nor rude & $<1 \%$ \\
\hline Rude & $0 \%$ \\
\hline Very rude & $100 \%$ \\
\hline \hline TOTAL & \\
\hline \hline
\end{tabular}

Table 3.14 shows that 63 percent of clients found the weatherization crew to be very careful and 30 percent said they were careful with the respondents' belongings. About four percent said they were careless or very careless.

Table 3.14 Carefulness of Weatherization Crew

\begin{tabular}{|l||c||}
\hline How careful of your home and belongings was the weatherization crew? & 659 \\
\hline \hline Number of Respondents & $63 \%$ \\
\hline \hline Very careful & $30 \%$ \\
\hline Careful & $3 \%$ \\
\hline Neither careful nor careless & $3 \%$ \\
\hline Careless & $1 \%$ \\
\hline Very careless & $100 \%$ \\
\hline \hline TOTAL & \multicolumn{2}{|c||}{$1 \%$} \\
\hline \hline
\end{tabular}


Findings on how clean the crew left the inside and outside of the home are presented in Table 3.15. A slightly larger percentage of clients rated the cleanliness of the outside of the house as very clean compared to the inside of the house. Forty-seven percent of clients said the crew left the inside of the house very clean and 42 percent said clean. In comparison, 55 percent of clients said the crew left the outside of the home very clean and 37 percent said it was left clean. In both cases, three percent or less said the crew left the home dirty.

Table 3.15 Cleanliness of Crew

\begin{tabular}{|c|c|c|}
\hline \multicolumn{3}{|c|}{ Overall, how clean did the weatherization crew leave the inside/outside of your home? } \\
\hline Number of Respondents & Inside (664) & Outside (659) \\
\hline Very clean & $47 \%$ & $55 \%$ \\
\hline Clean & $42 \%$ & $37 \%$ \\
\hline Neither clean nor dirty & $7 \%$ & $5 \%$ \\
\hline Dirty & $3 \%$ & $2 \%$ \\
\hline Very dirty & $<1 \%$ & $<1 \%$ \\
\hline TOTAL & $100 \%$ & $100 \%$ \\
\hline
\end{tabular}

Table 3.16 displays the results for client satisfaction with the final condition of the inside and outside of the home after weatherization. Fifty-eight percent of clients were very satisfied with the condition of the inside of the home, and 35 percent were satisfied. Similarly, 59 percent of clients were very satisfied with the condition of the outside of the home after the weatherization work was done, and 34 percent were satisfied.

Table 3.16 Satisfaction with Final Home Condition

\begin{tabular}{|l|c|c|}
\hline \multicolumn{2}{|l|}{ Overall, how satisfied were you with the final condition that the inside/outside of your home was left in? } \\
\hline \hline Number of Respondents & Inside (665) & Outside (659) \\
\hline \hline Very satisfied & $58 \%$ & $59 \%$ \\
\hline Satisfied & $35 \%$ & $34 \%$ \\
\hline Neither satisfied nor dissatisfied & $3 \%$ & $4 \%$ \\
\hline Dissatisfied & $3 \%$ & $3 \%$ \\
\hline Very dissatisfied & $1 \%$ & $<1 \%$ \\
\hline \hline TOTAL & $100 \%$ & $100 \%$ \\
\hline
\end{tabular}

\subsection{FINAL INSPECTION}

After the weatherization work is completed, an inspector from the agency visits the home and checks to make sure that all of the measures were correctly installed and are operating properly. During this visit, inspectors usually have a discussion with the client about what was done in the home, what maintenance of the installed measures is required (if any), and whether the client has any outstanding concerns. For many agencies, the inspector also is responsible for delivering energy education. 
The specific survey questions related to the final inspection included:

- Whether or not the final inspection had occurred

- $\quad$ Ease of scheduling the final inspection

- $\quad$ Timeliness of the crew

- $\quad$ Courteousness of the crew

Table 3.17 shows that 76 percent of clients had the final inspection of the home after the weatherization work was done, 19 percent had not had the final inspection at the time of the survey, and 5 percent did not know if it had taken place or not.

Table 3.17 Final Inspection Received

\begin{tabular}{|l|c|}
\hline Have you had a final inspection? \\
\hline \hline Number of Respondents & 665 \\
\hline \hline Yes & $76 \%$ \\
\hline No & $19 \%$ \\
\hline Don't Know & $5 \%$ \\
\hline \hline TOTAL & $100 \%$ \\
\hline \hline
\end{tabular}

As seen in Table 3.18, among those clients who had the final inspection, 62 percent found it very easy to schedule, and an additional 35 percent found it easy to schedule.

Table 3.18 Ease of Final Inspection Scheduling

\begin{tabular}{|l||c||}
\hline \multicolumn{2}{|l||}{ How easy was it to schedule the final inspection of your home? } \\
\hline \hline Number of respondents who had a final inspection & 502 \\
\hline \hline Very easy & $62 \%$ \\
\hline Easy & $35 \%$ \\
\hline Neither easy nor difficult & $2 \%$ \\
\hline Difficult & $1 \%$ \\
\hline Very difficult & $0 \%$ \\
\hline \hline TOTAL & $100 \%$ \\
\hline
\end{tabular}


Table 3.19 shows that 97 percent of clients who had a final inspection said that the people who did the inspection were either early or on time.

Table 3.19 Timeliness of Final Inspector

\begin{tabular}{|l||c||}
\hline \multicolumn{2}{|l||}{ How timely were the people who did the final inspections of your home? } \\
\hline \hline Number of respondents who had a final inspection & 501 \\
\hline \hline Early or on time & $3 \% \%$ \\
\hline$<30$ minutes late & $<1 \%$ \\
\hline 30 - 59 minutes late & $<1 \%$ \\
\hline 1 - 3 hours late & $0 \%$ \\
\hline$>3$ hours late & $0 \%$ \\
\hline Did not show up on scheduled day & $100 \%$ \\
\hline \hline TOTAL & $0 \%$ \\
\hline
\end{tabular}

Table 3.20 shows that of those who had a final inspection, the inspectors were perceived as very courteous by 75 percent, and courteous by an additional 22 percent.

Table 3.20 Courteousness of Final Inspector

\begin{tabular}{|l|c||}
\hline \multicolumn{1}{|l||}{ How courteous were the people who did the final inspection of your home? } & $50 \%$ \\
\hline \hline Number of respondents who had a final inspection & $22 \%$ \\
\hline \hline Very courteous & $2 \%$ \\
\hline Courteous & $<1 \%$ \\
\hline Neither courteous nor rude & $0 \%$ \\
\hline Rude & $100 \%$ \\
\hline Very rude & \\
\hline \hline TOTAL & \\
\hline
\end{tabular}





\section{CLIENT EDUCATION}

This section of the report furnishes findings on the extent to which clients received education services that helped them to understand ways to save energy and to improve health and safety in the home. The goal of the WAP program is to make client homes safer and more affordable. To achieve that, the program is to have trained professionals assess the performance of the home and to identify and install cost-effective energy efficiency measures and necessary health and safety measures. However, it also is important for clients to be active partners in saving energy and improving health and safety. The Satisfaction Survey asked clients to describe the extent to which the program furnished information on energy efficiency and health and safety, and to report on their satisfaction with that component of the program.

- Energy Education - The survey found that most, but not all, clients received energy education services. When they received services, the clients generally reported that the information was useful. However, compared to the investment in installation of energy efficiency measures and resolution of health and safety problems, the investment in direct energy education was modest and did not have a major impact on the client's weatherization experience. Most clients reported that they had less than 30 minutes of energy education. It is important to note, however, that the survey did not attempt to capture the on-going education that takes place during interactions between the client and different weatherization staff that come into the client's home.

- Health and Safety Education - The survey found that less than half of the weatherization clients reported that they had significant interactions with the weatherization program staff in terms of health and safety issues. Among those clients who had in-depth discussions about health and safety issues, it is clear that the clients understood some important messages about how to protect their health and the health of their families, both in terms of the safety of energy efficiency equipment and in terms of the impact of other factors on the indoor air quality in their homes. However, the service delivery process did not focus as much on health and safety as it did on energy efficiency.

These findings might suggest that the program could do more client education, particularly for health and safety issues. However, the survey only tells us about the experience of clients, not the reason for those experiences. With respect to energy efficiency education, many service delivery professionals suggest that they can be more useful to clients by engaging them in the weatherization process, rather than by talking about energy savings practices independent of the installed weatherization measures. In terms of health and safety education, service delivery staff may only focus on these issues for homes and households where there clearly is a problem. In both the Baseline Occupant Survey and in the Satisfaction Survey, the majority of clients did not report any major health issues or safety concerns. One possible interpretation of the results is that service delivery staff are responding to education opportunities, rather than conducting the same education with every client.

Overall, many clients are getting energy education and some clients are receiving health and safety education. While most clients seem satisfied with those services, it is not clear that they see this as a major benefit of the program. And, even for those clients who received education, it does not seem as if there has been a significant investment in terms of the time spent on it. The findings from this survey suggest that client education in the program is treated as client service that supports the weatherization process, rather than being a major focus of program delivery staff. If policymakers perceive that either energy education or health and safety education can deliver major benefits to low-income households, it 
seems that some change in either the delivery of those services or in the program guidance would be required to achieve level of benefit.

\subsection{ENERGY EDUCATION}

This section reviews client perceptions about the amount, content, and usefulness of energy education information provided by the program. The survey asked clients about discussions they had with the service delivery staff and the materials that they received from program staff. It also asked clients to report how much time they spent reviewing materials they received.

Table 4.1 shows that 69 percent of clients reported that they received information on ways to save energy in the home during the time of the weatherization visit. This included both discussions with service delivery staff and materials furnished by staff to the clients.

Table 4.1 Information Provided on Ways to Save Energy

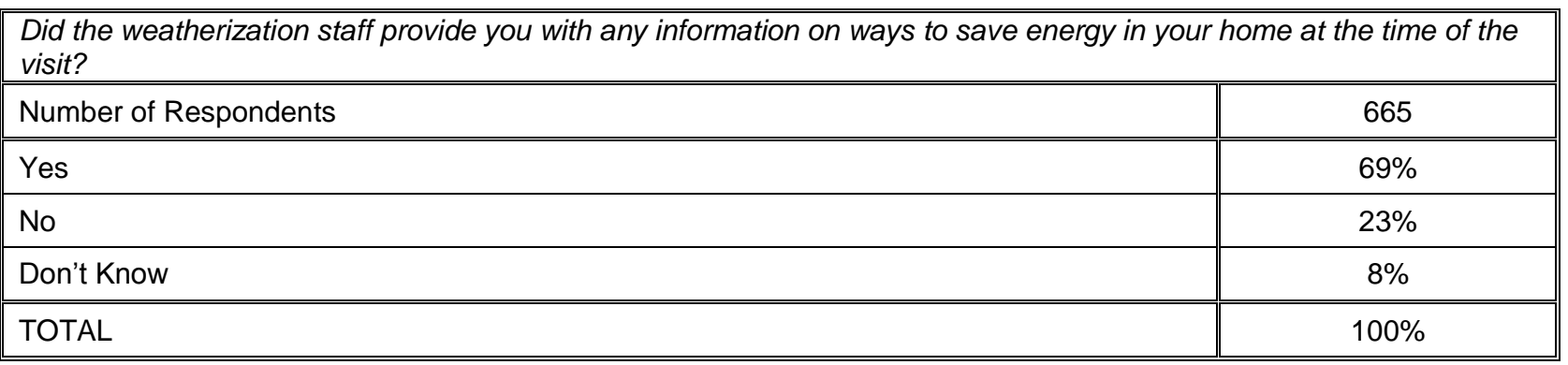

Table 4.2 presents results on the amount of time weatherization staff spent talking to clients about ways to save energy. About one-fourth of clients reported that staff spent 30 minutes or more talking to them about ways to save energy. But, the survey also found that about one-fourth of clients reported that staff did not spend any time discussing ways to save energy. 
Table 4.2 Time Spent Talking About Ways to Save Energy

\begin{tabular}{|l|c|}
\hline \multicolumn{2}{|l|}{ How much time did the weatherization staff spend talking to you about ways to save energy? } \\
\hline \hline Number of Respondents & 645 \\
\hline \hline No Time & $2 \%$ \\
\hline$<5$ minutes & $3 \%$ \\
\hline $5-14$ minutes & $17 \%$ \\
\hline $15-29$ minutes & $25 \%$ \\
\hline $30-60$ minutes & $18 \%$ \\
\hline$>1$ hour & $4 \%$ \\
\hline No information provided & $24 \%$ \\
\hline Don't know if information provided & $8 \%$ \\
\hline \hline TOTAL & $100 \%$ \\
\hline
\end{tabular}

Among those customers who spoke to staff about ways to save energy, most reported that they understood the information provided. Table 4.3 shows that among those who received information about energy saving, 70 percent said they understood the information very well and an additional 26 percent said they understood the information well.

Table 4.3 Understanding of Verbal Information Provided

\begin{tabular}{|l|c|}
\hline How well did you understand what the weatherization staff said to you about saving energy? \\
\hline \hline Number of respondents who received information from staff on ways to save energy & 457 \\
\hline \hline Very well & $70 \%$ \\
\hline Well & $26 \%$ \\
\hline Neither well nor not well & $1 \%$ \\
\hline Not well & $<1 \%$ \\
\hline Not well at all & $0 \%$ \\
\hline No time spent talking about saving energy & $3 \%$ \\
\hline \hline TOTAL & $100 \%$ \\
\hline
\end{tabular}

As seen in Table 4.4, 48 percent of clients reported that they received printed materials from the weatherization staff on saving energy. These printed materials were in the form of brochures, booklets or manuals. Two percent reported receiving other materials such as CDs, DVDs, or hardware kits of weatherization materials. 
Table 4.4 Staff Provided Educational Materials about Saving Energy

\begin{tabular}{|l|c||}
\hline \multicolumn{2}{|l||}{ What educational materials, if any, did the weatherization staff give you about saving energy ${ }^{4}$} \\
\hline \hline Number of respondents & 665 \\
\hline \hline One or more brochures, booklets, or manuals & $48 \%$ \\
\hline Other & $2 \%$ \\
\hline No materials were provided & $36 \%$ \\
\hline Don't know if materials were provided & $15 \%$ \\
\hline
\end{tabular}

Table 4.5 provides information on the amount of time spent reviewing materials. Over one-third of clients reported that they received materials and spent at least 15 minutes reviewing them. However, over one-half of the clients reported that they did not receive materials or they do not remember if they received any materials.

Table 4.5 Respondent Time Spent Reading or Reviewing Materials about Saving Energy

\begin{tabular}{|l|c||}
\hline $\begin{array}{l}\text { How much time have you spent reading or reviewing the materials about saving energy that the weatherization staff } \\
\text { gave you? }\end{array}$ & 665 \\
\hline \hline Number of respondents & $1 \%$ \\
\hline \hline No time & $2 \%$ \\
\hline 5 minutes 14 minutes & $10 \%$ \\
\hline $15-29$ minutes & $16 \%$ \\
\hline $30-60$ minutes & $15 \%$ \\
\hline$>1$ hour & $4 \%$ \\
\hline No materials provided & $36 \%$ \\
\hline Don't know if received materials & \\
\hline \hline TOTAL & $15 \%$ \\
\hline \hline
\end{tabular}

Table 4.6 shows that respondents had a good understanding of the materials weatherization staff provided on ways to save energy. Sixty-six percent of clients who received printed materials said they understood the materials very well, and 30 percent reported they understood them well.

\footnotetext{
${ }^{4}$ Respondents could provide more than one response for this question.

${ }^{5}$ This includes respondents who reported 'don't know' when asked whether weatherization staff provided any information on saving energy.

${ }^{6}$ This includes those who reported that the staff member only spent time demonstrating how to save energy.

7 This includes respondents who reported 'don't know' when asked whether weatherization staff provided any information on saving energy and those who replied 'don't know' when asked specifically whether weatherization staff provided any educational materials about saving energy.
} 
Table 4.6 Respondent Understanding of Materials about Saving Energy

\begin{tabular}{||l||c||}
\hline \hline How well did you understand the energy savings materials that the weatherization staff gave you? \\
\hline \hline Number of respondents who received printed materials from staff on ways to save energy \\
\hline \hline Very well & 319 \\
\hline Well & $30 \%$ \\
\hline Neither well nor not well & $1 \%$ \\
\hline Not well & $1 \%$ \\
\hline Not well at all & $0 \%$ \\
\hline No time spent reading materials & $2 \%$ \\
\hline \hline TOTAL & $100 \%$ \\
\hline
\end{tabular}

Staff-provided materials on energy savings were also perceived to be useful by clients, as shown in Table 4.7. Thirty-nine percent of clients who received printed materials found the materials very useful and 52 percent found them useful.

Table 4.7 Usefulness of Materials about Saving Energy

\begin{tabular}{|c|c|}
\hline \multicolumn{2}{|l|}{ How useful have the energy savings materials been to you? } \\
\hline Number of respondents who received printed materials from staff on ways to save energy & 317 \\
\hline Very useful & $39 \%$ \\
\hline Useful & $52 \%$ \\
\hline Neither useful nor not useful & $5 \%$ \\
\hline Not useful & $2 \%$ \\
\hline Not useful at all & $0 \%$ \\
\hline No time spent reading materials & $2 \%$ \\
\hline TOTAL & $100 \%$ \\
\hline
\end{tabular}

Respondents were asked what they found particularly useful about these materials. Table 4.8 shows that respondents were most likely to report that the tips for saving energy were most useful (61 percent). Other features that were reported to be useful included actual energy saving and easy to follow instructions. 
Table 4.8 Useful Features of Materials about Saving Energy

\begin{tabular}{|l|c|}
\hline What about the materials were particularly useful? $^{8}$ & 286 \\
\hline \hline Number of respondents who received printed materials and found it useful & $61 \%$ \\
\hline \hline Useful tips & $32 \%$ \\
\hline Actual energy savings & $18 \%$ \\
\hline Easy to follow instructions & $5 \%$ \\
\hline Non-energy tips & $8 \%$ \\
\hline Other & $11 \%$ \\
\hline Don't Know & \\
\hline \hline
\end{tabular}

Respondents who found the materials on energy savings to be less than very useful were asked what could be done to improve these materials. Table 4.9 shows the suggestions respondents provided for how materials on energy savings could be improved. Sixty-seven percent could not provide any suggestions for improvement, and 24 percent did not know how to improve the materials. The suggestions that were provided included more information, pictures, and more discussion with staff.

Table 4.9 Ways to Improve Materials about Saving Energy

\begin{tabular}{|l|c|}
\hline How could the materials have been improved for your use ? \\
\hline \hline Number of respondents who received printed materials and found it less than very useful & 187 \\
\hline \hline Contained more information & $5 \%$ \\
\hline Been discussed more by weatherization staff & $2 \%$ \\
\hline Provided pictures & $1 \%$ \\
\hline No suggested improvements & $67 \%$ \\
\hline Other & $3 \%$ \\
\hline Don't Know & $24 \%$ \\
\hline
\end{tabular}

Results on clients' overall satisfaction with information on ways to save energy are presented in Table 4.10. Almost all clients who receive information on ways to save energy were either satisfied or very satisfied with the information.

\footnotetext{
${ }^{8}$ Respondents could provide more than one response for this question.

${ }^{9}$ Respondents could provide more than one response for this question.
} 
Table 4.10 Overall Satisfaction with Energy Saving Information Provided

\begin{tabular}{|l|c|}
\hline \multicolumn{2}{|l|}{ How satisfied are you with the ways that the weatherization staff provided you with information about saving energy? } \\
\hline \hline Number of respondents who received information from staff on ways to save energy & 457 \\
\hline \hline Very satisfied & $54 \%$ \\
\hline Satisfied & $40 \%$ \\
\hline Neither satisfied nor dissatisfied & $5 \%$ \\
\hline Dissatisfied & $1 \%$ \\
\hline Very dissatisfied & $0 \%$ \\
\hline \hline TOTAL & $100 \%$ \\
\hline
\end{tabular}

With respect to energy education, the survey found that most, but not all, clients received energy education services. When they received services, the clients generally reported that the information was useful. However, it seemed that, compared to the investment in installation of energy efficiency measures and resolution of health and safety problems, the investment in direct energy education was modest and did not have a major impact on the client's weatherization experience. Most clients reported that they had less than 30 minutes of energy education.

\subsection{HEALTH AND SAFETY EDUCATION}

This section reviews client perceptions about the amount, content, and usefulness of health and safety information provided by the program. The survey specifically asked clients whether weatherization staff engaged them in discussions about health and safety issues, whether staff furnished materials, and whether they were referred to other services.

Table 4.11 shows that 36 percent of clients reported that they were asked about the health of household members by weatherization staff and 14 percent said that they provided household member health status information to the staff. However, in 37 percent of cases, no information about the health of household members was sought by weatherization staff or provided to them.

Table 4.11 Staff Knowledge about Health of Household Members

Did the weatherization staff ask you/did you provide them with any information about the health of the members of your household at any time during the process?

\begin{tabular}{|l||c||}
\hline \hline Number of Respondents & 665 \\
\hline \hline Staff asked about health of household members & $36 \%$ \\
\hline Respondent provided information about health of household members & $14 \%$ \\
\hline Staff didn't ask/respondent didn't provide information about health of household members & $37 \%$ \\
\hline Don't Know & $14 \%$ \\
\hline \hline TOTAL & $100 \%$ \\
\hline
\end{tabular}


Table 4.12 shows that among those clients who were asked or provided information about household member health to program staff, only five percent were in need of any health care at the time of the weatherization visit. Four of those 16 clients received help from weatherization staff to get the needed health care.

The responses to Table 4.12 furnish some context for the findings in Table 4.11. Among those households who were specifically asked about health issues, only 5 percent reported that they had unmet needs. If clients appear to have such a low rate of unmet needs, it is easy to understand why weatherization staff might feel that it was important to focus on other issues in their discussions with clients. However, even though this is a small percentage, it is appropriate for weatherization staff to ask screening questions related to health of household members so that those issues are not overlooked.

Table 4.12 Assistance for Household Members in Need of Health Care ${ }^{10}$

When the work crew came to your home, were any members of your household in need of health care, but not receiving it?

Number of respondents who were asked by staff or provided staff information about health of household members

\begin{tabular}{|l|c|}
\hline \hline Household members in need of healthcare & $5 \%$ \\
\hline No household members in need of healthcare & $95 \%$ \\
\hline \hline TOTAL & $100 \%$ \\
\hline
\end{tabular}

Table 4.13 shows that referrals for social services were more common than help with health care needs. Eleven percent of clients reported that weatherization staff referred them to social service programs. The most common referral was LIHEAP. Other referrals were made to housing assistance, food assistance programs, other energy programs, or roof repair, but these were less common.

\footnotetext{
${ }^{10}$ Note: In 2 cases the respondent should have received the question on the provision of information to the household, but did not. In these 2 cases, the respondent did give an answer to whether household members were in need of healthcare; these 2 cases are included in the base of both of these tables.
} 
Table 4.13 Referrals to Social Service Programs

\begin{tabular}{|l|c||}
\hline \hline $\begin{array}{l}\text { Did the weatherization staff or your weatherization agency refer you to any other housing and/or social service } \\
\text { programs? }\end{array}$ & $11 \%$ \\
\hline \hline Number of Respondents & 650 \\
\hline \hline Staff referred household to social services & $100 \%$ \\
\hline Staff did not refer client to any housing and/or social services & $69 \%$ \\
\hline \hline TOTAL & $3 \%$ \\
\hline \hline What program or programs did they refer you to ${ }^{11}$ & $2 \%$ \\
\hline \hline Number of Respondents & $1 \%$ \\
\hline \hline Low-Income Energy Assistance Program (ex. LIHEAP) & $1 \%$ \\
\hline Housing assistance program & $1 \%$ \\
\hline Food stamps and other food assistance programs & $1 \%$ \\
\hline Roof Repair & $89 \%$ \\
\hline Another Energy Program & $2 \%$ \\
\hline Medical care (MEDICAID, CHIP, etc) & \\
\hline Did not refer client to any housing and/or social services & \\
\hline Other & $1 \%$ \\
\hline
\end{tabular}

Table 4.14 shows that 40 percent of clients reported weatherization staff provided them with information on ways to improve health and safety in their homes. Table 4.15 shows that, among those clients who received some information, most reported that the amount of time spent was less than 15 minutes. Only one in five clients reported that they discussed health and safety issues for 15 minutes or more.

Table 4.14 Staff Provided Information on Ways to Improve Health and Safety in the Home

Did the weatherization staff provide you with any information on ways to improve health and safety in your home?

\begin{tabular}{|l|c||}
\hline \hline Number of Respondents & 665 \\
\hline \hline Yes & $40 \%$ \\
\hline No & $43 \%$ \\
\hline Don't Know & $17 \%$ \\
\hline \hline TOTAL & $100 \%$ \\
\hline
\end{tabular}

\footnotetext{
${ }^{11}$ Respondents could provide more than one response for this question.
} 
Table 4.15 Staff Time Spent Talking About Improving Health and Safety

\begin{tabular}{|l||c||}
\hline \multicolumn{1}{|l||}{ How much time did the weatherization staff spend talking to you about ways to improve health and safety? } \\
\hline \hline Number of Respondents & $1 \%$ \\
\hline \hline No time & $3 \%$ \\
\hline$<5$ minutes & $14 \%$ \\
\hline $5-14$ minutes & $14 \%$ \\
\hline $15-29$ minutes & $6 \%$ \\
\hline $30-60$ minutes & $1 \%$ \\
\hline$>1$ hour & $44 \%$ \\
\hline No information provided & $17 \%$ \\
\hline Don't know if received health and safety information ${ }^{12}$ & $100 \%$ \\
\hline \hline TOTAL & 602 \\
\hline \hline
\end{tabular}

Table 4.16 shows that clients who reported that staff provided verbal information about ways to improve health and safety in the home said they understood what they were told. Seventy-one percent understood the information very well and 27 percent understood it well.

Table 4.16 Respondent Understanding of Information on Improving Health and Safety

\begin{tabular}{|l||c||}
\hline \multicolumn{2}{|l||}{ How well did you understand what the weatherization staff said to you about improving health and safety? } \\
\hline \hline $\begin{array}{l}\text { Number of respondents who received information from staff on ways to improve health and } \\
\text { safety }\end{array}$ & 263 \\
\hline \hline Very well & $27 \%$ \\
\hline Well & $0 \%$ \\
\hline Neither well nor not well & $0 \%$ \\
\hline Not well & $0 \%$ \\
\hline Not well at all & $2 \%$ \\
\hline No time spent talking with weatherization staff & $100 \%$ \\
\hline \hline TOTAL & $27 \%$ \\
\hline \hline
\end{tabular}

About 40 percent of clients reported that they received verbal information on health and safety from the staff. However, Table 4.17 shows that fewer clients reported that they received printed materials on this topic. Twenty-two percent reported they were given brochures, booklets, or manuals. An additional two percent recalled that they received some other types of materials.

\footnotetext{
${ }^{12}$ This refers to respondents who reported "don't know" when asked whether weatherization staff provided any information on health and safety.
} 
Table 4.17 Health and Safety Materials Provided

\begin{tabular}{|l||c|}
\hline \multicolumn{2}{|l|}{ What materials, if any, about improving health and safety did the weatherization staff give you ? } \\
\hline \hline Number of Respondents & 664 \\
\hline \hline One or more brochures, booklets and manuals & $22 \%$ \\
\hline Other & $2 \%$ \\
\hline No materials were provided & $53 \%$ \\
\hline Don't know if health and safety materials were provided & $24 \%$ \\
\hline
\end{tabular}

Table 4.18 shows that ten percent of respondents said they spent less than 15 minutes reviewing materials on improved health and safety, eight percent spent 15 to 29 minutes, and five percent spent 30 minutes or more. Seventy-seven percent were not provided with (or did not recall receiving) any printed materials on this topic.

Table 4.18 Time Reviewed Health and Safety Materials

\begin{tabular}{|l||c||}
\hline \hline $\begin{array}{l}\text { How much time have you spent reading or reviewing the materials about improving health and safety that the } \\
\text { weatherization staff gave you? }\end{array}$ & 664 \\
\hline Number of Respondents & $1 \%$ \\
\hline \hline No time & $8 \%$ \\
\hline$<5$ minutes & $8 \%$ \\
\hline $5-14$ minutes & $4 \%$ \\
\hline $15-29$ minutes & $1 \%$ \\
\hline $30-60$ minutes & $53 \%$ \\
\hline$>1$ hour & $24 \%$ \\
\hline No materials provided & $100 \%$ \\
\hline Don't know if materials provided ${ }^{15}$ & $8 \%$ \\
\hline \hline TOTAL & $5 \%$ \\
\hline
\end{tabular}

\footnotetext{
${ }^{13}$ Respondents could provide more than one response to this question.

${ }^{14}$ This includes respondents who reported "don't know" when asked whether weatherization staff provided any information on health and safety.

${ }^{15}$ This includes respondents who reported "don't know" when asked whether weatherization staff provided any information on health and safety, and those who reported don't know when asked specifically whether weatherization staff provided any printed materials on health and safety.
} 
Table 4.19 shows clients' reports on understanding of the provided materials. The table shows that 68 percent said they understood the materials very well, and 28 percent understood them well.

Table 4.19 Respondent Understanding of Materials Provided About Improving Health and Safety

\begin{tabular}{||l||c||}
\hline \multicolumn{1}{|l||}{ How well did you understand the materials about improving health and safety that the weatherization staff gave you? } \\
\hline \hline $\begin{array}{l}\text { Number of respondents who received printed materials from staff on ways to improve health } \\
\text { and safety }\end{array}$ & $68 \%$ \\
\hline \hline Very well & $28 \%$ \\
\hline Well & $0 \%$ \\
\hline Neither well nor not well & $0 \%$ \\
\hline Not well & $0 \%$ \\
\hline Not well at all & 455 \\
\hline No time spent reading the materials & $100 \%$ \\
\hline \hline TOTAL & $0 \%$ \\
\hline \hline
\end{tabular}

Respondents who received printed materials on health and safety stated that they found them useful. Table 4.20 shows that 44 percent found these materials on health and safety to be very useful, and 41 percent said they were useful.

Table 4.20 Usefulness of Materials about Improving Health and Safety

\begin{tabular}{|l||c||}
\hline \multicolumn{2}{|l||}{ How useful have the materials about improving health and safety been to you? } \\
\hline \hline $\begin{array}{l}\text { Number of respondents who received printed materials from staff on ways to improve health } \\
\text { and safety }\end{array}$ & $44 \%$ \\
\hline \hline Very useful & $41 \%$ \\
\hline Useful & $8 \%$ \\
\hline Neither useful nor not useful & $2 \%$ \\
\hline Not useful & $1 \%$ \\
\hline Not useful at all & $4 \%$ \\
\hline No time spent reading the materials & $100 \%$ \\
\hline \hline TOTAL & $45 \%$ \\
\hline \hline
\end{tabular}

Respondents who indicated that the printed materials on improving health and safety were useful were asked to list the features they found particularly useful about them. These results are presented in Table 4.21. The two most commonly mentioned features were the warnings about dangerous materials in the home, mentioned by 32 percent of respondents and warnings about fire and CO hazards, mentioned by 30 percent of respondents. Fifteen percent of indicated that information on the proper use of new heating or cooling equipment was particularly useful. Twelve percent mentioned energy saving tips. Other features were mentioned by less than ten percent of respondents. 
Table 4.21 Useful Features of the Materials on Improving Health and Safety

\begin{tabular}{|l||c||}
\hline \multicolumn{2}{|l||}{ What about the materials was particularly useful? } \\
\hline \hline $\begin{array}{l}\text { Number of respondents who found printed materials from staff on ways to improve health } \\
\text { and safety useful }\end{array}$ & $32 \%$ \\
\hline \hline Warned about dangerous materials in home & $30 \%$ \\
\hline Warned about fire/CO hazards & $13 \%$ \\
\hline Gave proper use on new heating/cooling equipment & $12 \%$ \\
\hline Provided energy saving tips & $6 \%$ \\
\hline Gave occupant specific advice & $3 \%$ \\
\hline Warned about building structure and roofing & $2 \%$ \\
\hline Gave information on potential pest problems & $14 \%$ \\
\hline Other & $14 \%$ \\
\hline Don't Know & $3 \%$ \\
\hline \hline
\end{tabular}

Respondents were also asked for their suggestions on ways to improve these materials. Table 4.22 shows that more than half had no suggestions for improvements. Among the suggestions were that the materials should include more information and that the materials should be discussed more by the weatherization staff.

Table 4.22 How Materials on Health and Safety could be Improved

\begin{tabular}{|c|c|}
\hline \multicolumn{2}{|l|}{ How could the materials have been improved for your use $?^{17}$} \\
\hline $\begin{array}{l}\text { Number of respondents who read printed materials from staff on ways to improve health and } \\
\text { safety and found them less than very useful }\end{array}$ & 79 \\
\hline Contained more information & $3 \%$ \\
\hline Been discussed more by weatherization staff & $1 \%$ \\
\hline Been bilingual & $1 \%$ \\
\hline No suggested improvements & $58 \%$ \\
\hline Other & $4 \%$ \\
\hline Don't Know & $33 \%$ \\
\hline
\end{tabular}

Results on overall client satisfaction with printed materials on ways to improve health and safety in the home are presented in Table 4.23. More than half, 55 percent, said they were very satisfied with these materials, and an additional 40 percent were satisfied.

\footnotetext{
${ }^{16}$ Respondents could provide more than one response for this question.

${ }^{17}$ Respondents could provide more than one response for this question.
} 
Table 4.23 Satisfaction with Health and Safety Information

How satisfied are you with the ways that the weatherization staff provided you with information about improving health and safety?

Number of respondents who received information from staff on ways to improve health and safety

\begin{tabular}{|l|c|}
\hline Very satisfied & $55 \%$ \\
\hline Satisfied & $40 \%$ \\
\hline Neither satisfied nor dissatisfied & $5 \%$ \\
\hline Dissatisfied & $0 \%$ \\
\hline Very dissatisfied & $0 \%$ \\
\hline \hline TOTAL & $100 \%$ \\
\hline
\end{tabular}

Table 4.24 displays information on respondent suggestions for ways to improve how the program provides health and safety information. Eleven percent suggested that the agency should provide more information. Twenty-one percent could not provide an answer to this question and 9 percent had no suggestion. Fifty-five percent were very satisfied with the way the weatherization staff provided health and safety information.

Table 4.24 Potential Improvements to Health and Safety Information

\begin{tabular}{||l||c||}
\hline \hline \multicolumn{2}{|l||}{ How could the agency improve the ways that it provides health and safety ${ }^{18}$} \\
\hline \hline $\begin{array}{l}\text { Number of respondents who received information from staff on ways to improve health and } \\
\text { safety }\end{array}$ & $11 \%$ \\
\hline \hline More literature/information & $5 \%$ \\
\hline Other & $9 \%$ \\
\hline No improvement & $21 \%$ \\
\hline Don't Know & $55 \%$ \\
\hline Very satisfied with how information provided & \\
\hline \hline
\end{tabular}

With respect to health and safety education, the survey found that only some clients received health and safety information. When they received such information, the clients generally reported that it was useful. However, it seems that, compared to the investment in installation of energy efficiency measures and resolution of health and safety problems, the investment in direct education on health and safety issues was limited and did not have a major impact on the clients' weatherization experiences.

\footnotetext{
${ }^{18}$ Respondents could provide more than one response for this question.
} 


\section{OVERALL PROGRAM SATISFACTION}

The previous sections of this report present information on the individual components of the program, including each step in the weatherization process and the different types of education services delivered to clients. This section presents findings on the client satisfaction with and assessment of the services that the program delivered. The specific topics include:

- $\quad$ Areas for Improvement - A small percentage of the clients reported problems with installed measures and some perceived that their home could use additional measures.

- $\quad$ Overall Program Satisfaction - Clients report high levels of satisfaction with the quality of the work, with the performance of the installed equipment, and with the program overall.

- $\quad$ Satisfaction Benchmarks - Looking at both overall satisfaction and satisfaction with the individual program components, it is possible to see where the program is performing at the highest level, and where improvement could be made.

- Benefits - Clients reported that the program improved their comfort, lowered their energy bills, and made them feel more confident that they could afford to stay in their home.

The overall picture presented by the Satisfaction Survey is that the WAP program is very successful in meeting client needs. The program could do more to educate clients on energy efficiency opportunities and on way to improve health and safety. In addition, it might be possible for the program to give clients a better understanding of why certain measures are selected and others are not. But overall, clients perceive that the program is meeting their needs.

\subsection{AREAS FOR IMPROVEMENT}

Respondents were asked if they had any problems with the weatherization services. Table 5.1 shows that only ten percent of clients reported any problems with the services.

Table 5.1 Problems with Weatherization Services Received

\begin{tabular}{|l|c|}
\hline Did you have any problems with the weatherization services you received? \\
\hline \hline Number of Respondents & 664 \\
\hline Yes & $10 \%$ \\
\hline No & $90 \%$ \\
\hline TOTAL & $100 \%$ \\
\hline \hline
\end{tabular}

Respondents who had a problem with weatherization services were asked several follow-up questions about the problems they encountered and how they dealt with them. Table 5.2 shows that 30 percent (twenty clients) filed a complaint about the services. 
Table 5.2 Complaint Filed about Weatherization Services

\begin{tabular}{|l||c||}
\hline \hline Did you file a complaint about the weatherization services provided? & 67 \\
\hline \hline Number of respondents who had a problem with weatherization services received & $30 \%$ \\
\hline Yes & $70 \%$ \\
\hline \hline TOTAL & $100 \%$ \\
\hline
\end{tabular}

Respondents who filed a complaint were asked additional questions about the nature of the complaint, their satisfaction with how the complaint was handled, and what actions the agency could have taken to resolve the complaint. When asked about the nature of the weatherization complaint, half of the 20 respondents stated that one reason for the complaint was the measure installation, and nine respondents mentioned the materials and/or equipment. Three of the 20 respondents mentioned the crew as a reason for the complaint. Three respondents mentioned clean-up, and three had complaints about other aspects of the program.

Seven of the 20 respondents who filed a complaint reached a resolution of the situation about which they complained. One respondent was very satisfied with the resolution, three were satisfied, and three were neither satisfied nor dissatisfied. Of the 19 respondents who were not very satisfied with the resolution of their complaints, 12 stated that the agency could still act on their complaint to fix the problem. Three respondents felt the agency could have listened better. One respondent felt they could not have done anything differently, and two respondents did not know how the agency could have done a better job to resolve the complaint. Four respondents had other things they thought the agency could have done as well.

Respondents were asked if there were any other measures or equipment they thought should have been installed to help them save energy. Table 5.3 shows that 33 percent reported there were other measures or equipment they felt the weatherization staff should have installed in their home to save energy. Far more clients perceived that they needed additional energy saving measures than had problems with the measures installed. However, since measure installation decisions in the program are guided by costeffectiveness calculations, it is possible that clients would not understand why certain measures were not installed.

Table 5.3 Household Perceived Need for Additional Measures

\begin{tabular}{|l|c|}
\hline $\begin{array}{l}\text { Do you feel that any additional measures or equipment should have been installed in your home to help you save } \\
\text { energy? }\end{array}$ & 643 \\
\hline \hline Number of Respondents & $33 \%$ \\
\hline \hline Yes & $67 \%$ \\
\hline No & $100 \%$ \\
\hline \hline
\end{tabular}


The most commonly mentioned additional measure was window caulking, replacement, or repair, which was mentioned by 14 percent (Table 5.4). Insulation and door replacement or repair was mentioned by 5 percent. Other measures or equipment were mentioned by fewer than 5 percent. Since, in most cases, window replacement is not a cost-effective energy conservation measure (i.e., does not have a savings-toinvestment ratio of 1.0 or greater), but clients perceive that new windows would save energy, it is not surprising that almost one-half of client concerns are about windows.

Table 5.4 Additional Weatherization Measures

\begin{tabular}{|c|c|}
\hline \multicolumn{2}{|c|}{ What other measures or equipment should have been installed $?^{19}$} \\
\hline Number of Respondents & 637 \\
\hline Window caulking, window repair or replacement & $14 \%$ \\
\hline Insulation & $5 \%$ \\
\hline Door repair or replacement & $5 \%$ \\
\hline Furnace repair or replacement & $3 \%$ \\
\hline Refrigerator & $3 \%$ \\
\hline Other appliances & $3 \%$ \\
\hline Air conditioner repair or replacement & $2 \%$ \\
\hline Water heater repair or replacement & $2 \%$ \\
\hline Ventilation repair or replacement & $2 \%$ \\
\hline Weather stripping & $1 \%$ \\
\hline Roof repair or replacement & $1 \%$ \\
\hline Air-sealing & $1 \%$ \\
\hline Other & $3 \%$ \\
\hline No additional measures needed & $68 \%$ \\
\hline
\end{tabular}

\footnotetext{
${ }^{19}$ Respondents could provide more than one response for this question.
} 
Another challenge for the program is home repairs. Many homes need major repairs, but the program often does not have the funding to make them. Table 5.5 shows that 46 percent of clients were aware that the weatherization staff checked to see if major repairs were needed, 17 percent said their home needed major repairs, and 12 percent reported the repairs were made. These statistics show that the program is making repairs that allows delivery of weatherization services to proceed. However, in some homes, the repairs were not completed. Presumably this was because the problem did not prevent the agency from installing appropriate weatherization measures.

Table 5.5 Staff Checked for Major Repairs

Did the weatherization staff check your home for major repairs, such as roof repairs, at any time during the process? Did they say repairs were needed in your home? Were major repairs done to your home?

\begin{tabular}{|l|c|}
\hline \hline Number of Respondents & 665 \\
\hline \hline Checked for repairs & $46 \%$ \\
\hline Repairs were needed & $17 \%$ \\
\hline Major repairs done to home & $12 \%$ \\
\hline
\end{tabular}

Table 5.6 presents clients' suggestions for program improvement. The table shows that 62 percent of clients had no suggestions for program improvements. Nine percent suggested more funding and approved installations, eight percent suggested better communication regarding the process, and eight percent suggested improving the quality of materials, crew or inspections.

Table 5.6 Suggestions for Program Improvement

\begin{tabular}{|l||c||}
\hline \multicolumn{2}{|l||}{ What suggestions, if any, do you have for how the weatherization program can be improved? } \\
\hline \hline Number of Respondents & 665 \\
\hline \hline More funding/approved installations & $9 \%$ \\
\hline Be more upfront with process/better communication & $8 \%$ \\
\hline Improve quality of materials/crew/work/inspections & $4 \%$ \\
\hline Faster weatherization process & $62 \%$ \\
\hline No suggested improvements & $4 \%$ \\
\hline Other & $7 \%$ \\
\hline Don't Know & \\
\hline \hline
\end{tabular}

\footnotetext{
${ }^{20}$ Respondents could provide more than one response for this question.
} 


\subsection{OVERALL PROGRAM SATISFACTION}

In Section 3 of the report, clients reported high rates of satisfaction with the different stages of weatherization service delivery. Clients report similar levels of satisfaction with the final outcome of the service delivery process. Table 5.7 shows that clients were well satisfied with the weatherization work that was done in their home. Sixty percent were very satisfied and 33 percent were satisfied.

Table 5.7 Overall Satisfaction with Work Done

\begin{tabular}{|l||c||}
\hline \multicolumn{2}{|l||}{ Overall, how satisfied are you with the work performed in your home? } \\
\hline \hline Number of Respondents & 664 \\
\hline \hline Very satisfied & $30 \%$ \\
\hline Satisfied & $4 \%$ \\
\hline Neither satisfied nor dissatisfied & $2 \%$ \\
\hline Dissatisfied & $<1 \%$ \\
\hline Very dissatisfied & $100 \%$ \\
\hline \hline TOTAL & $4 \%$ \\
\hline \hline
\end{tabular}

Similarly, Table 5.8 shows that clients were well satisfied with the new equipment installed in their home through this program. Sixty-two percent reported they were very satisfied and 30 percent reported they were satisfied.

Table 5.8 Overall Satisfaction with New Equipment Installed

\begin{tabular}{||l||c||}
\hline \multicolumn{1}{|l||}{ How satisfied are you with any new equipment installed in your home? } & 647 \\
\hline \hline Number of Respondents & $62 \%$ \\
\hline \hline Very satisfied & $30 \%$ \\
\hline Satisfied & $4 \%$ \\
\hline Neither satisfied nor dissatisfied & $2 \%$ \\
\hline Dissatisfied & $1 \%$ \\
\hline Very dissatisfied & $100 \%$ \\
\hline \hline TOTAL & $2 \%$ \\
\hline \hline
\end{tabular}

Table 5.9 displays the findings on client satisfaction with the energy savings. Thirty-eight percent of clients reported that they did not know if they had saved any energy after weatherization, 35 percent were very satisfied with their energy savings, and 22 percent were satisfied. Three percent reported that they did not save any energy. 
Table 5.9 Satisfaction with Energy Savings after Weatherization

\begin{tabular}{||l||c||}
\hline \hline After having your home weatherized, did you save any energy? & 665 \\
\hline \hline Number of Respondents & $59 \%$ \\
\hline \hline Saved energy after weatherization & $3 \%$ \\
\hline Did not save energy after weatherization & $38 \%$ \\
\hline Don't Know & $100 \%$ \\
\hline \hline TOTAL & 662 \\
\hline \hline How satisfied are you with the energy savings achieved after having your home weatherized? & $35 \%$ \\
\hline \hline Number of Respondents & $22 \%$ \\
\hline \hline Very satisfied & $2 \%$ \\
\hline Satisfied & $0 \%$ \\
\hline Neither satisfied nor dissatisfied & $0 \%$ \\
\hline Dissatisfied & $3 \%$ \\
\hline Very dissatisfied & $38 \%$ \\
\hline Did not save energy & $100 \%$ \\
\hline Don't know if saved energy & \\
\hline \hline TOTAL & 3 \\
\hline
\end{tabular}

Table 5.10 shows that overall program satisfaction was high. Sixty-three percent of clients reported they were very satisfied with the weatherization program and 31 percent were satisfied.

Table 5.10 Overall Satisfaction with the Weatherization Program

\begin{tabular}{|l||c||}
\hline \multicolumn{2}{|l||}{ Rate your overall satisfaction with the weatherization program. } \\
\hline \hline Number of Respondents & 665 \\
\hline \hline Very satisfied & $31 \%$ \\
\hline Satisfied & $4 \%$ \\
\hline Neither satisfied nor dissatisfied & $1 \%$ \\
\hline Dissatisfied & $<1 \%$ \\
\hline Very dissatisfied & $100 \%$ \\
\hline \hline TOTAL & 4 \\
\hline
\end{tabular}




\subsection{SATISFACTION BENCHMARKS}

Table 5.11 summarizes client satisfaction with various components of the program. The percentage of the total sample of clients who said they were very satisfied with each component of the program is presented. Clients reported the highest levels of satisfaction, around 60 percent very satisfied, with the program overall, the new equipment installed, the work performed in the home, and the condition of the inside and outside of the home the after weatherization work crew was done.

Table 5.11 Overall Satisfaction with Key Components of the Program

\begin{tabular}{|c|c|c|}
\hline \multicolumn{3}{|l|}{ How satisfied are you with the ___ ? } \\
\hline \multirow[t]{2}{*}{ Number of Respondents } & \multicolumn{2}{|c|}{665} \\
\hline & Very Satisfied & Satisfied \\
\hline $\begin{array}{l}\text { Length of time between request to have home weatherized and when it was } \\
\text { weatherized }\end{array}$ & $44 \%$ & $39 \%$ \\
\hline Final condition of the inside of the home & $58 \%$ & $35 \%$ \\
\hline Final condition of the outside of the home & $59 \%$ & $33 \%$ \\
\hline Work performed in the home & $60 \%$ & $33 \%$ \\
\hline New equipment installed in the home & $61 \%$ & $30 \%$ \\
\hline Energy savings achieved after having the home weatherized & $35 \%$ & $22 \%$ \\
\hline Information on saving energy & $37 \%$ & $28 \%$ \\
\hline Information on improving health and safety & $22 \%$ & $16 \%$ \\
\hline Overall Weatherization Program & $63 \%$ & $31 \%$ \\
\hline
\end{tabular}

Client satisfaction was substantially lower for the length of time between the request for weatherization and receipt of services, the way in which staff provided information about ways to save energy in the home, and actual energy savings achieved in the home. Only 35 percent of clients were very satisfied with the energy savings they achieved after weatherization and 22 percent were very satisfied with the way the staff provided information on improving health and safety in the home.

Table 5.12 is a summary table showing client perceptions of the ease of dealing with different aspects of the program. The percentages of clients who rated each part of the program as "very easy" or "easy" are presented. Scheduling the final inspection appears to be the easiest part of the program; 62 percent said it was very easy and 35 percent said it was easy. Fifty-three percent said scheduling the weatherization crew was very easy, 40 percent said it was easy. Forty-nine percent rated the scheduling of the audit as very easy, and 45 percent said this function was easy. Forty percent said the initial request for services was very easy, and 47 percent said it was easy. 
Table 5.12 Ease of Dealing with Different Aspects of the Program

\begin{tabular}{|l|c|c|c||}
\hline \hline How easy was it to_? & Respondents & Very Easy & Easy \\
\hline \hline & 657 & $40 \%$ & $47 \%$ \\
\hline Request that the home be weatherized & 660 & $49 \%$ & $45 \%$ \\
\hline Schedule the initial audit & 661 & $53 \%$ & $40 \%$ \\
\hline Schedule the weatherization crew to come to home & 502 & $62 \%$ & $35 \%$ \\
\hline Schedule the final inspection & &
\end{tabular}

Table 5.13 summarizes client perceptions of the timeliness of various components of the program. More than 90 percent of clients said that program staff were either early or on time for the initial audit, the weatherization services, and the final inspection.

Table 5.13 Timeliness of Various Components of the Program

\begin{tabular}{|l||c|c||}
\hline \hline How timely was/were_? & Respondents & $\begin{array}{c}\text { Percent who said } \\
\text { 'early or on time' }\end{array}$ \\
\hline \hline The people who did the initial audit of the home & 651 & $95 \%$ \\
\hline The weatherization crew & 658 & $93 \%$ \\
\hline The people who did the final inspection of the home & 501 & $97 \%$ \\
\hline \hline
\end{tabular}

\subsection{OVERALL PROGRAM BENEFITS}

Table 5.14 displays findings on client perceptions of the benefits of program participation. The three benefits mentioned most often by respondents were improved comfort ( 47 percent) improved home equipment (46 percent), and lower energy bills (43 percent).

Table 5.14 Benefits of Program Participation

\begin{tabular}{|l||c||}
\hline \hline What are some of the greatest benefits your household received by participating in the weatherization program? & 639 \\
\hline \hline Number of Respondents & $47 \%$ \\
\hline More comfortable home & $46 \%$ \\
\hline Improved home equipment & $43 \%$ \\
\hline Hower energy bill & $13 \%$ \\
\hline Health benefits for household members & $6 \%$ \\
\hline Environmental benefits & $2 \%$ \\
\hline Tips given by staff & $2 \%$ \\
\hline Other & $4 \%$ \\
\hline \hline
\end{tabular}

\footnotetext{
${ }^{21}$ Respondents could provide more than one response to this question.
} 
Table 5.15 shows that many clients tell others about WAP. Seventy-nine percent of clients told others about the program and 19 percent said the person they told received services. Twenty-three percent said the person they referred did not receive services and 38 percent did not know the outcome of their referral.

Table 5.15 Word of Mouth Referral

\begin{tabular}{|l||c||}
\hline \hline $\begin{array}{l}\text { In the last } 12 \text { months, have you told other people who might be interested in receiving weatherization services about } \\
\text { the program? }\end{array}$ & 659 \\
\hline \hline Number of Respondents & $79 \%$ \\
\hline \hline Told others about the program & $21 \%$ \\
\hline Did not tell others about the program & $100 \%$ \\
\hline \hline TOTAL & 659 \\
\hline \hline $\begin{array}{l}\text { Have those people had their homes weatherized, or are they scheduled to have their home weatherized, as a result } \\
\text { of your suggestion? }\end{array}$ & $19 \%$ \\
\hline \hline Number of Respondents & $23 \%$ \\
\hline \hline They got weatherized/are scheduled to be weatherized & $21 \%$ \\
\hline They did not receive services & $38 \%$ \\
\hline Did not tell others about the program & $100 \%$ \\
\hline Don't Know & \\
\hline \hline TOTAL & \\
\hline
\end{tabular}

Tables 5.16 and 5.17 furnish statistics on the likelihood that a household will move from their weatherized home. Table 5.16 shows that 80 percent of clients reported that they were less likely to move from their home and 12 percent reported no change in their likelihood of moving. Table 5.13 shows that 58 percent of clients reported that they were very unlikely to move in the next 12 months and 27 percent reported that they were unlikely to move. Only five percent were either very likely or likely to move in the next year.

Table 5.16 Impact of Services on Likelihood of Moving

\begin{tabular}{|l|c||}
\hline \hline $\begin{array}{l}\text { Do you think weatherization will have any impact on how long you stay in your current home? Would you say you are } \\
\text { Number of Respondents }\end{array}$ & 665 \\
\hline \hline More likely to move from your home & $2 \%$ \\
\hline Less likely to move from your home & $80 \%$ \\
\hline Equally likely to move from your home & $12 \%$ \\
\hline Already moved & $1 \%$ \\
\hline Don't Know & $5 \%$ \\
\hline \hline TOTAL & $100 \%$ \\
\hline \hline
\end{tabular}


Table 5.17 Likeliness Household Will Move in Next 12 months

\begin{tabular}{|l||c||}
\hline \multicolumn{2}{|l||}{ How likely is your household to move in the next 12 months for any reason or combination of reasons? } \\
\hline \hline Number of Respondents & 658 \\
\hline \hline Very likely & $3 \%$ \\
\hline Likely & $4 \%$ \\
\hline Neither likely nor unlikely & $27 \%$ \\
\hline Unlikely & $58 \%$ \\
\hline Very unlikely & $4 \%$ \\
\hline No chance & $1 \%$ \\
\hline Already moved & $100 \%$ \\
\hline \hline TOTAL & $3 \%$ \\
\hline
\end{tabular}

Overall, clients perceive that the program has benefited them by making their homes more comfortable and making it easier to stay in their homes. They tell other low-income households about these program benefits and find that many of the people they tell about the program also receive services. 